Review Article

\title{
Sustainable Development of Carbon Nanocomposites: Synthesis and Classification for Environmental Remediation
}

\author{
Dhinakaran Veeman $\left(D,{ }^{1}\right.$ M. Varsha Shree, ${ }^{1}$ P. Sureshkumar ${ }^{D},{ }^{2}$ T. Jagadeesha, ${ }^{3}$ \\ L. Natrayan $\left(1,{ }^{4}\right.$ M. Ravichandran $\left(10,{ }^{5}\right.$ and Prabhu Paramasivam $(1)^{6}$ \\ ${ }^{1}$ Centre for Additive Manufacturing, Chennai Institute of Technology, -600069, Chennai, India \\ ${ }^{2}$ Department of Mechanical Engineering, Ramco Institute of Technology, Rajapalayam, Virudhunagar, Tamil Nadu, India \\ ${ }^{3}$ Department of Mechanical Engineering, National Institute of Technology, Calicut, India \\ ${ }^{4}$ Department of Mechanical Engineering, Saveetha School of Engineering, SIMATS, Chennai, Tamil Nadu 602105, India \\ ${ }^{5}$ Department of Mechanical Engineering, K. Ramakrishnan College of Engineering, Tiruchirappalli, 621112 Tamil Nadu, India \\ ${ }^{6}$ Department of Mechanical Engineering, College of Engineering and Technology, Mettu University, Ethiopia -318
}

Correspondence should be addressed to Dhinakaran Veeman; dhinakaranv@citchennai.net,

L. Natrayan; natrayanphd@gmail.com, and Prabhu Paramasivam; prabhuparamasivam21@gmail.com

Received 12 July 2021; Revised 7 August 2021; Accepted 27 August 2021; Published 20 September 2021

Academic Editor: Lakshmipathy R

Copyright (c) 2021 Dhinakaran Veeman et al. This is an open access article distributed under the Creative Commons Attribution License, which permits unrestricted use, distribution, and reproduction in any medium, provided the original work is properly cited.

\begin{abstract}
Composite materials with carbon nanotube and graphene attachments have been regarded as promising prospects. Carbon nanocomposites have gained considerable interest in different fields including biomedical applications due to its exceptional structural dimensions and outstanding mechanical, electrical, thermal, optical, and chemical characteristics. The significant advances made in carbon nanocomposite over past years along with the discovery of new nanocomposite processing technologies to improvise the functional impact of nanotube and graphene composites by providing proper methods of synthesis and improving the production of diverse composite based on carbon nanomaterials are discussed. Carbon nanocomposites are applied in various fields such as aviation, batteries, chemical industry, fuel cell, optics, power generation, space, solar hydrogen, sensors, and thermoelectric devices. The recent design, fabrication, characteristics, and applications of carbon nanocomposites such as active carbon, carbon black, graphene, nanodiamonds, and carbon nanotubes are explained in detail in this research. It is found that unlike traditional fiber composites, Van der Waals force interfacial compounds have an important effect on the mechanical performance of carbon nanomaterial-based composites.
\end{abstract}

\section{Introduction}

The incessant demand for the commercial usage of engineered carbon-based nanomaterials are increasing in the field of modern technology, medicine, environment, and agriculture; the distinctive properties of carbon-based nanomaterials have engrossed great concentration by the researchers and industrialists which have stimulated the expansion and innovation techniques for significant industrial production [1]. Carbon is among the stimulating elements, with the capacity to produce wide range of arrangements, habitually with diverse characteristics [2]. Some of the significant allotropes of carbon encompass "hard" diamond and "soft" graphite [3]. The inno- vative constituents that are carbon nanotubes (CNTs), fullerenes, graphene, and engrossed high contemplation from scientific industries which exhibit varieties of exceptional features as encouraging resources for abundant application fields due to their special capabilities, they were recurrently labelled as "wonder materials" [4]. The allotropical carbon transition, known as fullerenes, is generally a chemical component of carbon, or carbon particles. Here, carbon atoms naturally exist in the form of $\mathrm{sp}^{2}$-hybrid and are bound by covalent bonds. Fullerene (C60) is a highly symmetrical spherical compound with 60 carbon atoms, at the tip of 20 hexagons and 12 pentagons $[5,6]$. Carbon nanotubes (CNT) are the most notable of carbon-based nanomaterials; 
CNTs are one of the carbon allotropes with excellent mechanical properties, characterized by tubular structures with a width of only a few nanometres, consisting of rolled graphene sheets and often varying in chirality, diameter, and weight $[7,8]$. Graphene is a $2 \mathrm{D}$ allotropic carbon group consisting of "single layers of sp2-hybridized carbon atoms" in a $0.142 \mathrm{~nm}$ outcrop of $2 \mathrm{D}$ hexagonal crystal lattice between adjacent hexagonal carbon atoms [9]. It has various physicochemical properties, such as unusually high structural rigidity and higher thermal stability, and the electrical properties of graphene are very different from those of 3 dimensional products [10]. Intensively developed the discovery of carbon-based nanomaterials and their study of superior characteristics, synthesis methods, culminating in the basic component called carbon vapour, which manipulates the production of carbon nanomaterials [11]. The buoyant physical and chemical characteristics of carbon-based nanomaterials influence various applications that, in effect, allow their production to intensify [12]. Figure 1 displays the variations of the carbon nanocomposites. Carbon nanostructures contain numerous low-dimensional allotropes of carbon including carbon black (CB), carbon fiber, carbon nanotubes (CNTs), fullerene, and graphene.

By achieving several thousand tons of products [14], the carbon nanotubes have resulted in industrial development being the broadest area of operation. Due to the mechanical features of CNT such as high tensile strength and improved stability, they are integrated into polymers and other resources to manufacture structural and composite materials with innovative properties as required by their application and specification [15]. Carbon nanocomposites have exhibited exceptional catalytic activity in organic chemical processes due to their shape-dependent physical and chemical properties and thickness, primarily metal nanostructures or carbon materials consisting of graphene and carbon nanotubes [16]. The catalytic yield from the use of carbon nanocomposites in various fields, including nutritional, pharmaceutical, and materials sciences for biotechnology [17], has been found to be of great value. The catalytic products produced using carbon nanocomposites are considered of great value in various fields, particularly in medicinal, biomedical, agricultural, and material sciences $[18,19]$. Consequently, demand for carbon nanocomposites has increased rapidly and therefore the development of new methods of preparation deserves a high degree of interactivity [20]. Nanocomposite benefits involve module enhancement, flexural strength, thermal distortion, barrier effects, and other advantages and, unlike conventional mineral-reinforced systems, are with no typical impact and visibility trade-offs.

\section{Methods of Synthesis of Carbon Nanocomposites}

2.1. Covalent Functionalization. Covalent functionality uses covalent connection of functional elements to the carbon scaffold of the nanotube. It can be of two forms, covalent side-wall functionalization and defect functionalization, depending on the location of contact. The functioning of the direct covalent sidewall implies a shift in hybridisation

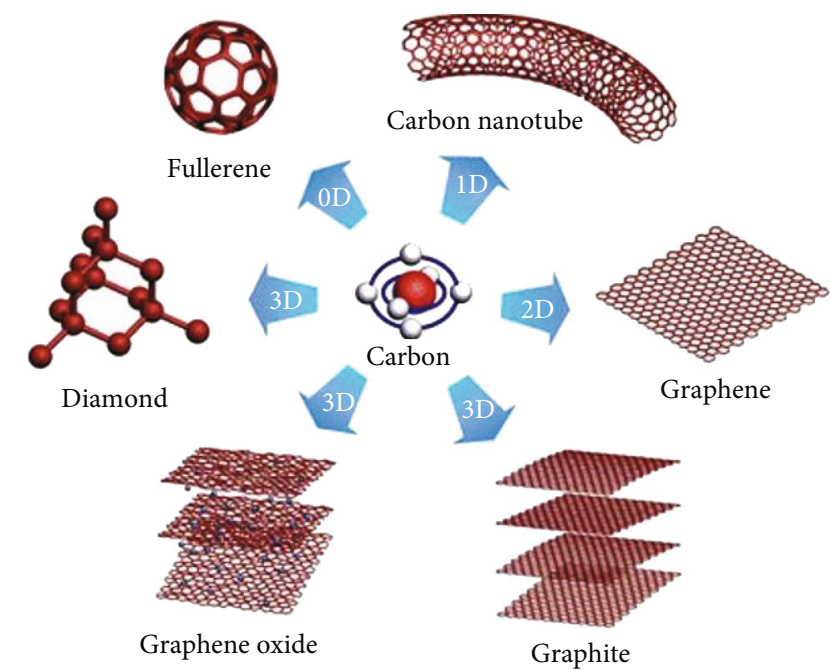

FIgURE 1: Classification of carbon nanocomposites [13].

from $\mathrm{sp}^{2}$ to $\mathrm{sp}^{3}$ and conjugation loss [21]. Functionalization of defects is based on the already existing site modifications [22]. Defect sites may include the open ends and the sidewall holes ended in hexagonal graphene framing, e.g., by functional groups and defects in stone/wales (5-7 faults). Oxidative purification also includes oxygenated sites produced as faults. SWCNTs have poor dispersibility and are shown as bundles [23]. The use of a highly reactive reagent for the covalent bond creation of the walls is guaranteed in this circumstance. It cannot be said in advance whether such additional reactions are most likely to occur at defective locations or intact hexagonal areas of the edge [24]. Several covalent methods, such as oxidative purification, amidation, esterification, thiolation, halogation, hydrogenation, and electrochemical functionality, have been adopted for covalent functionalization [25].

2.2. Noncovalent Functionalization. The noncovalent functionalization also known as supramolecular correlations is found across all types of materials which are exposed to attractive or repulsive forces, common in both organic and inorganic structures [26]. In the case of graphene, assigning defects or irregularities arising from the transition from $\mathrm{sp}^{2}$ carbon to $\mathrm{sp}^{3}$ carbon, though combining multiple relations, is technically useful [27]. Graphene materials and energy dissociation of less than $50 \mathrm{~kJ} \mathrm{~mol}^{-1}$ [28] have a prevailing relationship. A major component to be addressed in graphene and graphene oxide (GO) systems is solvation and hydrophobic effects induced by various interactions, as they affect not only their dispersibility but also the identification of associations that can be used to classify them [29]. Graphene has two forms of interactions that influence its compatibility with other nanomaterials or stimulants between electron-rich and electron-poor regions [30]. This is often seen on both face-to-face arrangement and edge-to-face arrangement [31]. Also present in biologically relevant molecules such as DNA, RNA, and porphyrins through electron interactions. In addition, these interactions are found in small molecules and are transmitted to GO and G systems 
where they can be used to process and modify properties [32]. The effective dispersion of graphene was accomplished by noncovalent functionalization with amine-packed and fully packed polymers [33]. Reduced graphene in nonsolvents could be spread by noncovalent grafting with an end-functional PS- $\mathrm{NH}_{2}$ polymer [34]. For noncovalent functionalization, numerous nonsolvents for reduced graphene, benzene, hexane, oxylene, and dichloromethane, which are immiscible with the aqueous process, were used [35]. The remaining carboxylate groups effectively provided the noncovalent functionalization locations to the protonated amine terminals of end-functional polymers after the chemical reduction of graphene oxide [36]. The noncovalent functionality promoted the transmission of graphene sheets from the water phase to the organic phase through simple sonication [37]. Figure 2 displays the noncovalent functionalization of carbon nanocomposites. Here, chitosan is packed more firmly when covalently connected to the surface of CNTs than when noncovalently functionalized CNTs. Atomic force microscopy (AFM) might be used to assess the efficacy of macromolecule coating. This figure shows Chit-f-CNT preparation (top), AFM height images (middle), and profile measurements (bottom) for pure CNT (left), Chit noncovalent functionalized CNT (centre), and Chit covalent connected CNT (right).

2.3. Wet Synthesis. Metal oxide nanoparticles are an important class of nanomaterials which find numerous scientific and technological applications. The selective surface design, step, size, and shape of nanoparticles of metal oxides can be achieved by the use of wet chemical propagation which contributes to the collection of desired properties [39]. Developments in the synthesis of metal oxide nanoparticles are noteworthy due to their use in the electronics and optics as metal oxide nanoparticles and nanocomposites are becoming more popular in applied ecology, particularly as adsorbents and photo catalysts, and also a resource for the fabrication of environmental monitoring systems [40] and catalytic and energy storage industries [41]. Metal oxides are naturally capable of isolating the metal oxide charges [42]. Nanomaterial synthesis is split into two types: topdown approach and bottom-up approach [43]. In the topdown process, a large part of the substance is broken up into nanosized bodies [44].

It takes a complicated, costly, extremely energy-intensive, and sophisticated system to sustain precise conditions such as atmosphere, heat, and temperature [46]. Top-down methodology creates nonuniform, surface-defected nanomaterials that obstruct practical application [47]. From the bottom up, the atomic or molecular agents for the formation of nanostructures are incorporated into the process. The downstream approach is largely based on humid chemicals being processed fairly scalable and flexibility [48]. The method of wet chemical synthesis has made great progress as it benefits from using a kinetic and thermodynamic provision that can alter the scale, structure, and formulation of the electronic, optical, and interface properties [49]. Wet chemical processing methods for replicating desirable shape and size of metal oxide nanoparticles have been implemented. To generate ultrafine, extremely homogenous, and high purity powders, wet chemical techniques such as sol-gel, coprecipitation, and hydrothermal synthesis were developed [50]. The control of shape and size is accomplished by a better understanding of the fundamental events, the cycle by transforming the precursor, the surface stabilizing factor, and the reagent of the system and its interaction with the rate of proliferation and nucleation [51, 52]. A standard conventional batch technique will produce nanoparticles with a total scaling capacity of $10 \mathrm{mg} / \mathrm{m}$ [53]. The synthesis process should be versatile in terms of product quality and quantity to meet industrial specifications in order to understand the profitable functioning of colloidal metal oxide [54]. Figure 3 represents the chemical, physical, and biological approach for the synthesis of nanocomposites.

2.4. Dry Synthesis. The dry synthesis is known to be an extremely effective and adequate process for carbon nanocomposite propagation. The main benefits of this strategy are its versatility, enhanced adherence, and the advantages of the least design variables [55]. The dry synthesis has been described as the method ideally suited for the carbon decoration of metal nanoparticles [56]. The functional oxygen groups can bridge the metal nanoparticles and the carbon resources [57] through. Carbon materials with no usable surface groups may also be used consistently in carbon nanocomposite processing [58].

Nguyen-Tri et al. have established a method of quick and less dry solvent synthesis for the production of carbon nanocomposite [60]. A two-step direct process involves dry mixing of the metal precursor salt with carbon materials (CNTs or GO), followed by inert atmospheric heating [61]. No solvent, no additional reducing agents, or applied electric current are needed for the mechanochemical cycle [62]. Studies find that the mechanochemical method typically applies not only to CNTs but also to other carbon products with a high thermal conductivity, such as graphene, GO, and activated carbon [63]. The mechanochemical approach is considered rapid, adaptable, and ultimately versatile, allowing it to be used in various applications [64] for further usage. It covers possible uses in fields such as anticorrosion, antiwear, super hydrophobic area, self-cleaning, antifouling, antibacterial area, and electronics, as it is close to carbon nanocoating and it is represented in Figure 4 [65].

\section{Classification of Carbon Nanocomposite}

3.1. Carbon Black Nanocomposite. Polyaniline or carbon black (PANI/CB) nanocomposite structures and properties are particularly sensitive to chemical synthesis constraints [66]. It was found when the derived structures shifted from globular to a multitude of globular and nanofiber-like configurations by altering aniline and $\mathrm{CB}$ composition [67]. Complex nanostructures and synergistic capabilities [68] have been shown to produce the synthesis of conductive polymers and carbon-based substances. PANI/CB nanocomposites have better radiative stability and greater electrical conductivity compared to graphene-based nanotubes or nanocomposites [69]. The lightest PANI nanostructures 


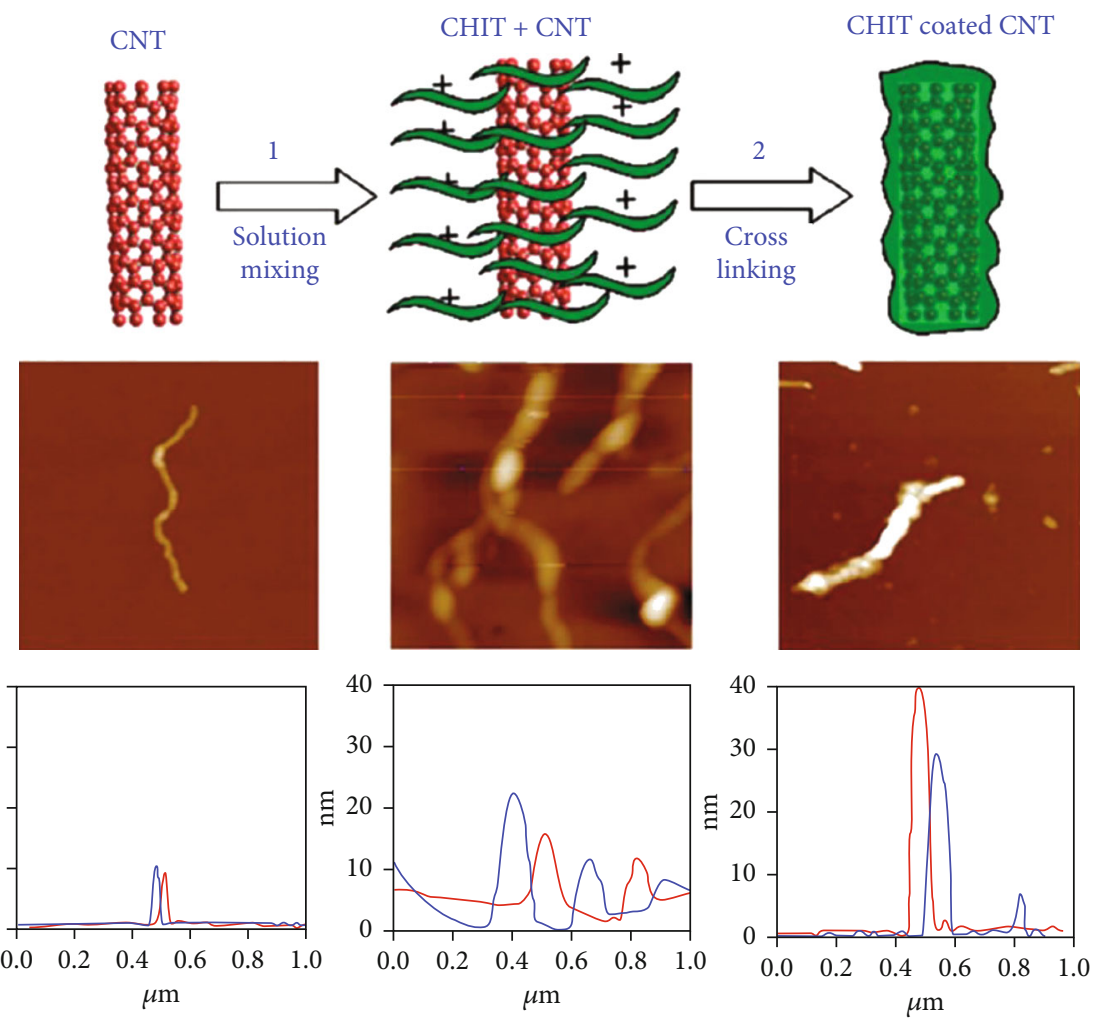

FIgURE 2: Noncovalent functionalisation of carbon [38].

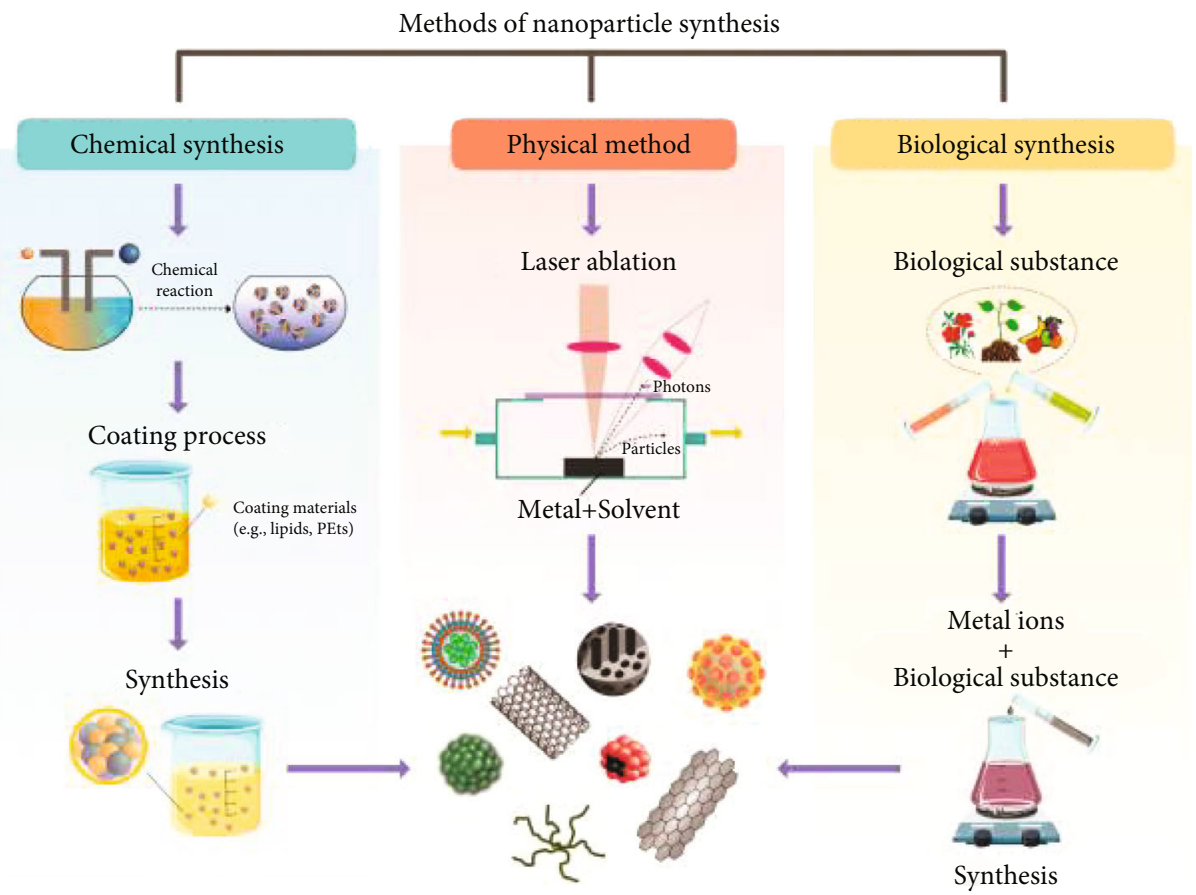

Figure 3: Wet synthesis of nanocomposites [45].

would have a significant number of heterogeneous crystallization sites to strengthen, avoid assembly, and increase nano particular nucleation dispersion [70]. In addition to carbon black $(\mathrm{CB})$, carbon fibers, melamine fibers, and mica numer- ous reinforcement fillers have been used to enhance the mechanical properties of the finished products. Indeed, CB still retains the most significant global contribution [71]. Nanofillers, especially nanoclay (NC), have replaced 


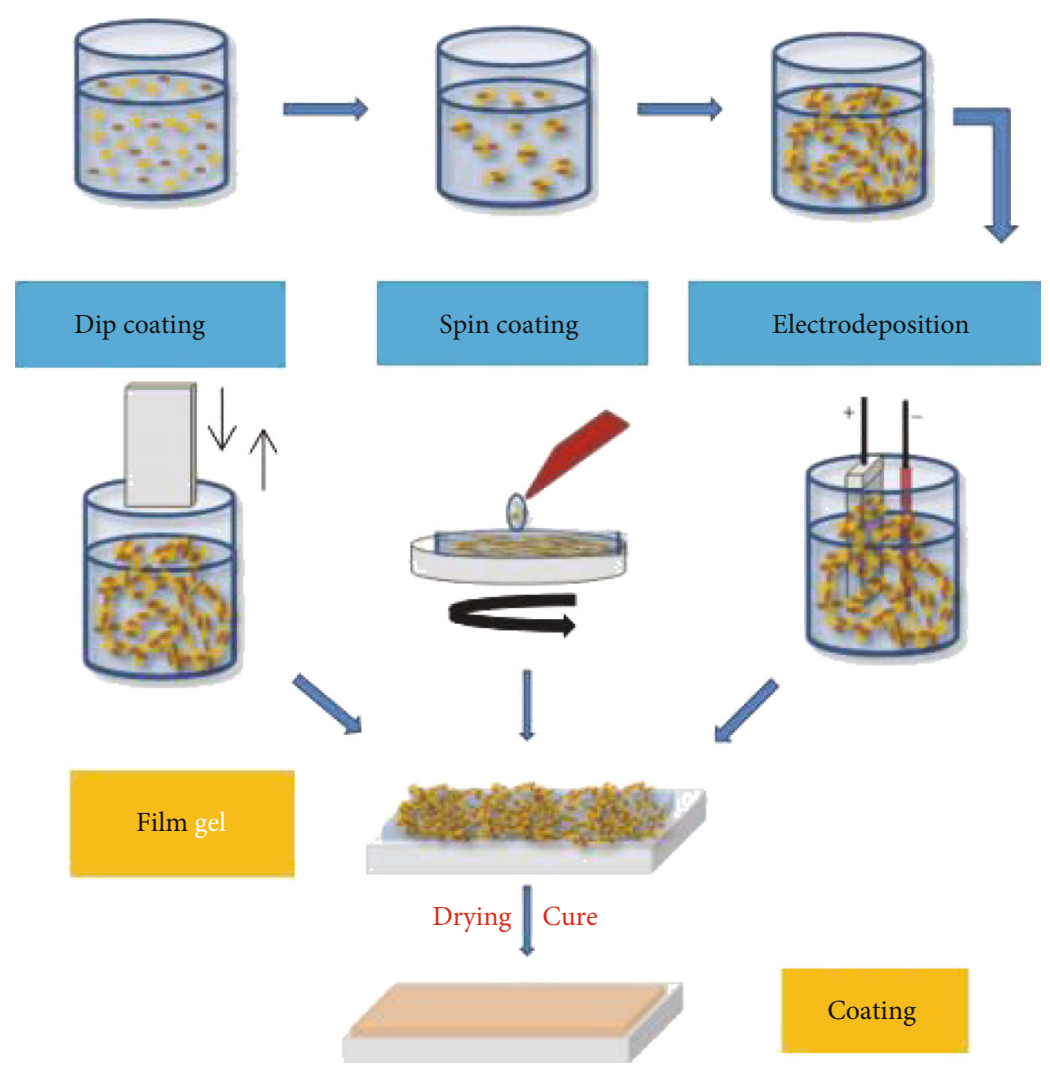

Figure 4: Dry synthesis of carbon nanocomposites [59].

traditional micro fillers in modern times by providing a higher surface area which correlates in much better interaction between molecular fillers [72, 73].

Based on the mechanical behaviour of nanocomposites [75], the feasible formulation of a dual filler frame in NBR matrix is researched. The impact of NC and NBR matrix interfacial communication on synergistic influence of $\mathrm{NC}$ and $\mathrm{CB}$ is explored [76]. Studies have also shown that involvement with $\mathrm{CB}$, greater dispersal of $\mathrm{NC}$ in natural rubber, and rubber with styrene butadiene may be achieved [77]. Nanocomposites based on NBR/CB/NC and the mechanical and microstructural tests of subsequent hybrid systems have been configured to use NC and CB simultaneously [78, 79]; Figure 5 highlights methods for the synthesis of black carbon nanocomposite. The effects of heat treatment on carbon black (CB) nanocomposites are shown in Table 1.

3.2. Composites Based on Carbon Nanotubes. In the last few decades, the scope and application of nanotechnology have had an extraordinary effect on carbon nanomaterials. The university has been flush with fresh ideas, innovations, and many attempts to identify the ultimate uses for such amazing nanostructures, starting with the finding of fullerenes and going through the $\mathrm{CO}_{2}$ era to graphene and other double-dimensional (2D) materials [81]. In this section, one such application which looked close to incorporating these materials when initially presented, but which did not meet expectations for different reasons: composite materials.
In particular, the problem of whether mechanical reinforcing structures like carbon nanotubes and graphene are the correct option remained largely unsolved and was prominently reinforced in composite matrices due to their mechanical characteristics. In addition, careful assessment and thinking are needed in the field of functionality to be obtained by inserting nanotubes against graph in a matrix [82]. Although the two are $\mathrm{sp}^{2}$ allotropes, their structure, morphology, and dimensionality, and the nature of their interactions, with the surrounding matrix, are actually extremely different [83]. The overall mechanical composite behaviour of these two reinforcing units could therefore be distinctive [84]. It would certainly be helpful to have selection procedures in composite applications, however, in nanocomposites with CNT or graphene phases such logical techniques are not developed.

Nanostructured composite polymer materials have created new insights for multipurpose materials. Carbon nanotubes (CNTs) directly provide possible applications for the enhancement of mechanical and electrical performance in aerospace laminates [86, 87]. A new composite substance with enhanced electromagnetic properties forms the combination of epoxy resin with double-walled carbon nanotubes [88]. Documentation of nanotubes distributed in polymer matrix was intended to improve the electrical and mechanical properties of polymer composites $[89,90]$. The covalent and noncovalent functionalization processes have been suggested as one of the options for improved nanotube distribution [91]. Molecular modification of the nanotube 


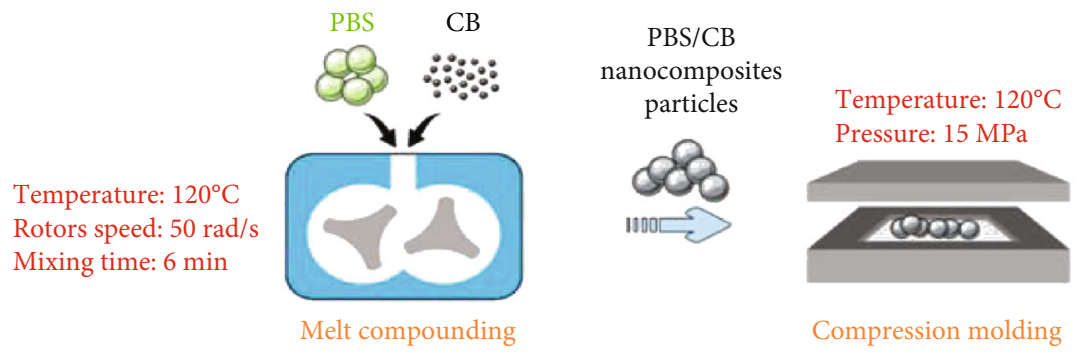

$\mathrm{PBS} / \mathrm{CB}$

nanocomposites foams

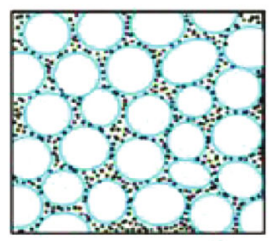

$\mathrm{PBS} / \mathrm{CB}$ nanocomposites plates
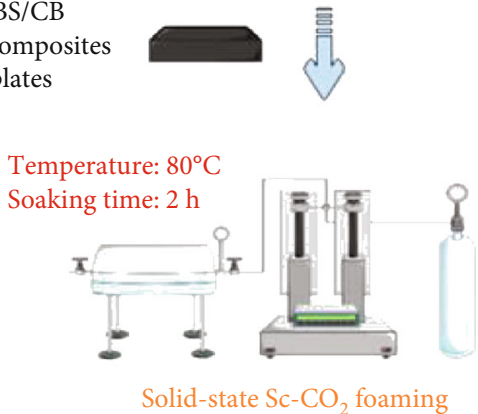

FIGURE 5: Synthesis of carbon black nanocomposite [74].

TABLE 1: Effects of heat treatment on carbon black (CB) nanocomposites [80].

\begin{tabular}{lccccccccc}
\hline CB sample & NSA $\left(\mathrm{m}^{2} / \mathrm{g}\right)$ & $\mathrm{STSA}\left(\mathrm{m}^{2} / \mathrm{g}\right)$ & $\mathrm{O}(\%)$ & $\mathrm{N}(\%)$ & $\mathrm{H}(\%)$ & $\mathrm{S}(\%)$ & $\mathrm{C}(\%)$ & $\mathrm{Lc}(\mathrm{nm})$ & $\mathrm{d} 002(\mathrm{~nm})$ \\
\hline $\mathrm{N} 234$, untreated & 126.4 & 120.3 & 2.21 & 0.145 & 0.337 & 0.924 & 93.7 & 1.19 & 0.365 \\
$\mathrm{~N} 234,900^{\circ} \mathrm{C}$ & 134.7 & 124.7 & 1.28 & 0.158 & 0.250 & 0.932 & 95.9 & 1.15 & 0.361 \\
$\mathrm{~N} 234,1000^{\circ} \mathrm{C}$ & 129.6 & 129.6 & 0.204 & 0.064 & 0.130 & 0.916 & 96.7 & 1.40 & 0.361 \\
$\mathrm{~N} 234,1200^{\circ} \mathrm{C}$ & 129.0 & 132.8 & 0.128 & 0.041 & 0.021 & 0.790 & 98.7 & 1.44 & 0.355 \\
N660, untreated & 36.4 & 35.2 & 0.576 & 0.082 & 0.339 & 1.84 & 95.9 & 1.78 & 0.352 \\
N660, $1000^{\circ} \mathrm{C}$ & 36.4 & 37.3 & 0.110 & 0.056 & 0.141 & 1.78 & 96.8 & 1.59 & 0.355 \\
\hline
\end{tabular}

substratum by covalent functionalization decreases the aspect ratio with the formation of carbon atoms $\mathrm{sp}^{3}$ on the nanotube layer [92]. That reduces the power conductivity of nanotubes [93]. The cylindrical CNT specification allows them to obtain a so-called electronic conjugate framework which reflects their distinctive behaviour in electronic transport [94]. Composites incorporated in a polymer host were used for microwave operations [95] as well as for electromagnetic interference shielding (EMI) or microwave absorbers such as antireflection [96]. The advent of CNTs as filler components has contributed to the production of CNT-polymer nanocomposites as the sophisticated structural material of the next century [97]. The A polyacrylonitrile (PAN)/polyvinylidene fluoride (PVDF) nanofibers achieved a high $\mathrm{CO}_{2}$ absorption of $2.21 \mathrm{wt}$ percent and demonstrated efficiency in reversible $\mathrm{CO}_{2}$ capture under flow gas pressures [98]. Magnetic composites based on carbon nanotubes (CNTs) have huge potential for the discovery and use of magnetic solid-phase extraction (MSPE) technology [99, $100]$. Figure 6 represents the classification of carbon nanotubes based on their structural arrangements.

3.3. Graphene-Based Carbon Nanocomposites. Graphene is one of the world's finest materials and has developed consid- erable interest in physics, materials science, chemistry, and biology. Graphene has a very high conductivity in electricity and thermal efficiency, making it the best incentives for thermally conductive composites [101]. Films used as the heating element are more smart than conventional heating elements because of lower environmental pollution, easy to use on various surface areas, and have the characteristics of lightweight [102]. At the forefront of nanotechnology are carbon-based nanomaterials from earlier C60 and carbon nanotubes into graphene [103].

The monolayer graphene is dense on a single surface and can be separated from graphite using adhesive by standard graphite flake exfoliation [105]. Classification and detachment of substantial lateral dimension of pristine graphene at high solvent concentrations are difficult. Tiny layer of graphene is containing roughly $2-10$ sheets of graphene atoms, like flakes [106]. This was a by-product that was created during attempts to render monolayer graphene. Ultrathin graphite is a graphite substance greater than $3-5 \mathrm{~nm}$ in diameter but less than $100 \mathrm{~nm}$ [107]. Graphene oxide is a strongly oxidized graphene produced by intense crystal graphite oxidation followed by sonication or some other dispersion phase, typically in aqueous absorption, forming a monolayer material [108]. Reduced graphene oxide is the 


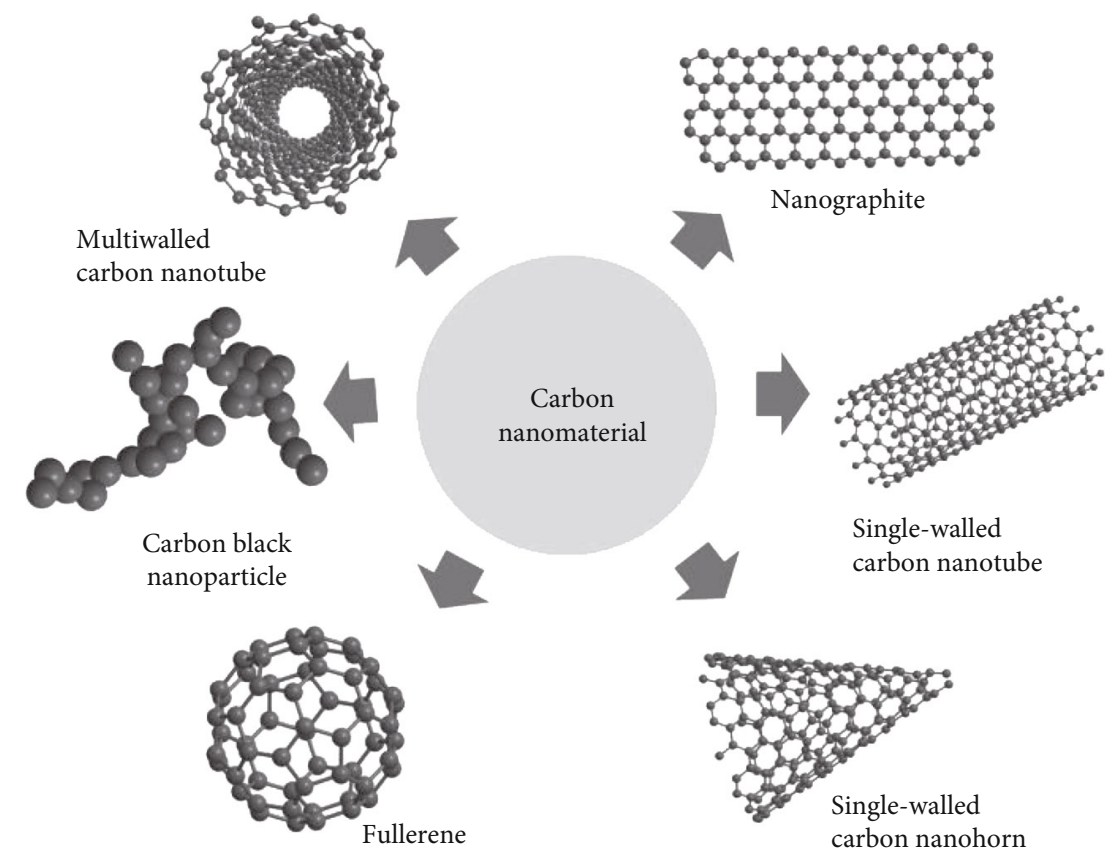

FIGURE 6: Classification of carbon nanotubes based on their structures [85].

substance produced by treating GO under reduced conditions, such as thermal processing at high temperatures [109]. Decreasing GO also influences many of its properties, such as reducing its oxygen content [110], increasing its hydrophobicity, creating $\mathrm{CO} / \mathrm{CO}_{2}$ emission holes or defects in the carbon lattice [111], and reducing its surface load and water supply [112]. Also, the basal planes contain unchanged, hydrophobic, and capable graphene domains of $\pi-\pi$ interactions associated with dye molecules or other drugs adsorption [113]. Figure 7 displays graphene nanocomposite structure.

The van der Waals binding of the walls of carbon nanotubes to individual layers of multilayer graphic must also be considered in layered reinforcement. Compared to the strong covalent bonding of the graph layers, this link is rather weak [114]. Therefore, when multiwalled carbon nanotube (MWNT) and multilayer graphene are employed in composites, their capacity to strengthen is restricted by simple cuts between the walls or between the layers [115]. The inner stress transmission between the nanotube walls of carbon and the graph layers may be monitored by variations in the Raman-related stress band [116]. Imperfect stress transmission occurs during deformation as the Raman band is extended, and the Raman band shift is lowness compared to the single-wall or single-level material. Comparing Raman bands stress shifts in epoxy nanocomposites for single walled carbon nanotube (SWNT) and MWNT indicate that efficiency for transferring stress from interwalls for MWNTs is only approximately 70\% [117]. Compared to the large number of research on CNT and graphene reinforced polymer matrix composites, the focus on ceramic or metal composites was significantly less, maybe because of limited production [118]. Furthermore, in polymer-based composites, mechanical strengthening effects are more evident. CNTs or ceramic graphic composites are driven pri- marily by increased toughness or resistance to fracture formation because ceramics are already stiff and solid [119]. The major toughening process is the higher energy dissipation owing to graphene nanosheet pull for graphene-enhanced ceramic composites [120]. Other difficult processes discovered include crack deflection and crack bridging on the matrix reinforcement interface. In CNT-reinforced ceramic composites, similar toughening mechanisms were also reported. Improved thermal and electrical conduction is also possible [121]. Graphene plays a vital role in removal of heavy material; they are shown in Table 2.

3.4. Activated Carbon Nanocomposites. Activated carbon, also known as activated charcoal, is a type of carbon treated with small, lower volume holes that enhance the area of the surface [123]. Because of its significant degree of microporosity, one gram of activated carbon has an area of more than $3,000 \mathrm{~m}^{2} / \mathrm{g}$, as calculated by gas adsorption [124]. $\mathrm{ZnO}$ or activated carbon nanocomposites are produced by physically combining the $\mathrm{ZnO}$ nanoparticles produced with activated carbon [125]. The proportion of nanoparticles to activated charcoal for the adsorption of $\mathrm{Cd}^{2+}$ from aqueous solutions was standardized $(9: 1)$ [126]. These carbon nanocomposites are produced by mechanically combining the $\mathrm{ZnO}$ nanomaterials excreted above with activated carbon [127]. The concentration scope of activated carbon nanocomposites of $0.15-1.5 \mathrm{mg} / \mathrm{ml}$ has been used to evaluate $\mathrm{Cd}^{2+}$ formulated at concentrations between 10 and $100 \mathrm{ppm}$ [128]. A sonicator probe has been used to create agitation for the adsorption of cadmium ions through vibration energy [129]. The higher adsorption power and good magnetic segregation efficiency of magnetic activated carbon are $\mathrm{Fe}_{3} \mathrm{O}_{4}$ [130] and can be used as possible sorbents for the extraction of multiple toxic contaminants from wastewater [131]. The $\mathrm{M}$ versus $\mathrm{H}$ curves for $\mathrm{Fe}_{2} \mathrm{O}_{3}$ nanoparticles and $\mathrm{Fe}_{3} \mathrm{C}$ 


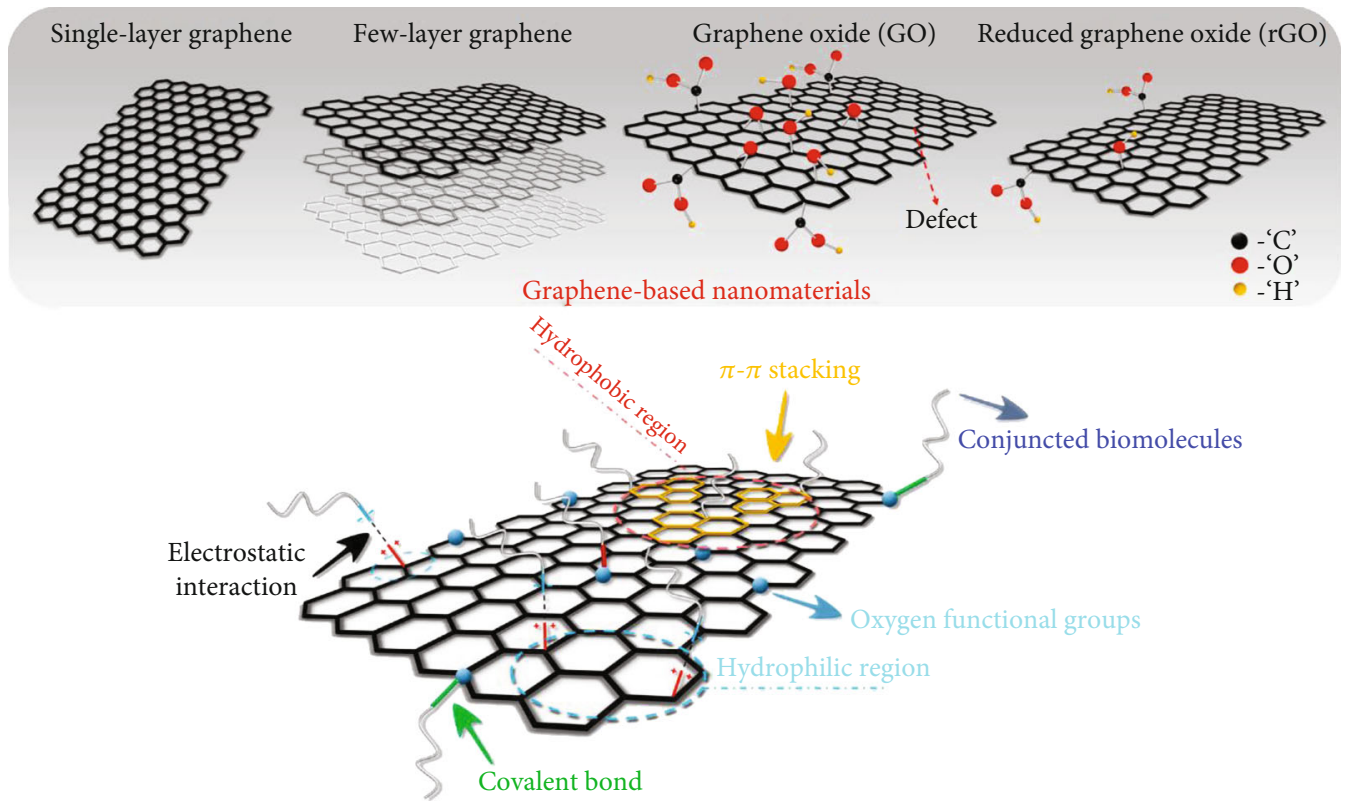

Functionalization of graphene-based nanomaterials

FIGURE 7: Structure of graphene-based nanocomposite [104].

TABLE 2: Graphene nanocomposites for heavy metal removal [122].

\begin{tabular}{|c|c|c|}
\hline Adsorbent & Adsorbate & Maximum adsorption capacity $\left(\mathrm{mg} \mathrm{g}^{-1}\right)$ \\
\hline Functionalised GOCA beads & $\mathrm{Pb}(\mathrm{II}), \mathrm{Hg}(\mathrm{II})$, and $\mathrm{Cd}$ (II) & 602,374 , and 181 \\
\hline GO/PAMAMs & $\mathrm{Pb}$ (II), Cd (II), $\mathrm{Cu}(\mathrm{II})$, and $\mathrm{Mn}$ (II) & $568.18,253.81,68.68$, and 18.29 \\
\hline $\mathrm{CS} / \mathrm{GO}-\mathrm{SH}$ & $\mathrm{Pb}$ (II), Cd (II), Cu (II) & 425,447, and 177 \\
\hline MMSP-GO & $\mathrm{Pb}$ (II), Cd (II) & 333 and 167 \\
\hline PVK-GO & $\mathrm{Pb}(\mathrm{II})$ & 887.98 \\
\hline $\mathrm{MnFe}_{2} \mathrm{O}_{4} / \mathrm{GO}$ & $\mathrm{Pb}$ (II), As (II), and As (V) & 673,146, and 207 \\
\hline EDTA-mGO & $\mathrm{Pb}$ (II), $\mathrm{Hg}$ (II), Cu (II) & $508.4,268.4$, and 301.2 \\
\hline Go/L-Trp & $\mathrm{Cu}(\mathrm{II})$ and $\mathrm{Pb}(\mathrm{II})$ & 588 and 222 \\
\hline PAH-GO & $\mathrm{Cu}(\mathrm{II})$ & 349.04 \\
\hline GO-CD-PPY NC & $\mathrm{Cr}(\mathrm{VI})$ & 666.67 \\
\hline $\mathrm{RGO} / \mathrm{NiO}$ & $\mathrm{Cr}(\mathrm{VI})$ & 198 \\
\hline PAS-GO & $\mathrm{U}(\mathrm{VI})$ and $\mathrm{Eu}(\mathrm{VI})$ & 310.63 and 243.90 \\
\hline Chitosan/GO & $\mathrm{Cr}(\mathrm{VI}), \mathrm{Cu}(\mathrm{II})$, and $\mathrm{Pb}(\mathrm{II})$ & $461.3,4238$, and 310.4 \\
\hline
\end{tabular}

MWCNT is shown in Figure 8. The adsorption process in activated carbon is distinct for organic and inorganic impurities. Activated carbon has the maximum removal effect for most organic contaminants. When activated carbon-quartz sand combination procedures were used, organic contaminants species and overall peak area may be decreased at the same time. However, the effects of phthalates, esters, and aldehydes were not substantially the same as dimethyl phthalate and di-nbutyl phthalate [132].

A basic progressive impregnation approach has been used to obtain some transition metal hexacyanoferrate [134], also known as microporous activated carbon composites [135] where in activated carbons are recognized as effective for many contaminants collected, having high surface area and formed porosity [120]. An activated carbon and iron oxide nanocomposite was developed and defined by the methods of X-ray diffraction and scanning electron microscopy [136]. Figure 9 represents the nanocomposite based on active carbon.

In order to synthesise polysulfone- (PSF-) activated nanocomposites, a melt-mixing method was utilised. This study examined the properties of thermal, mechanical, magnetic, morphological, and carbon dioxide capturing and utilised $2-w t \%$ activated carbon (CA, CA-Ni, and CO-Co) as a filler. The pyrolysis of the sawdust wood produced carbon compounds activated by Co and/or Ni Salt. The heat degradation and metal amount of carbon compounds were investigated. Thermogravimetric analysis is an effective method of measuring the polymer material thermal stability [137]. With the addition of metal-activated carbons, the beginning 


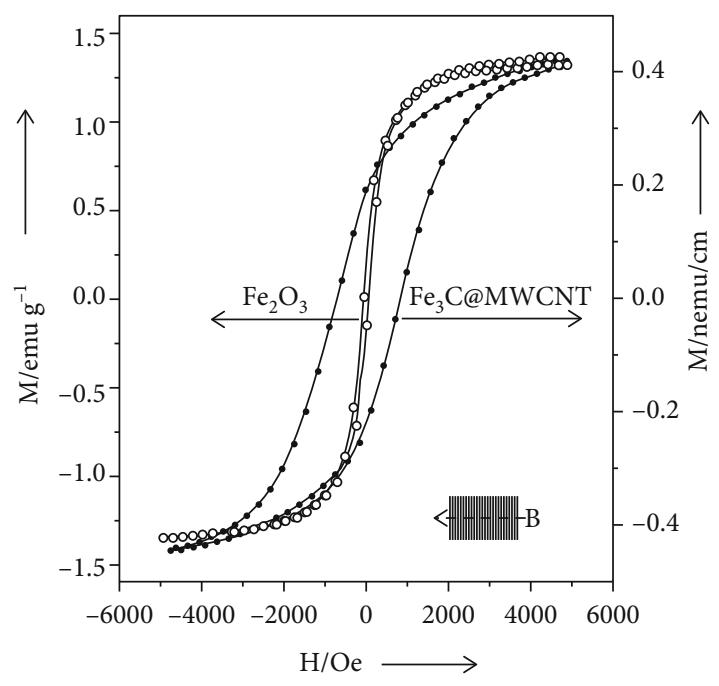

(a)

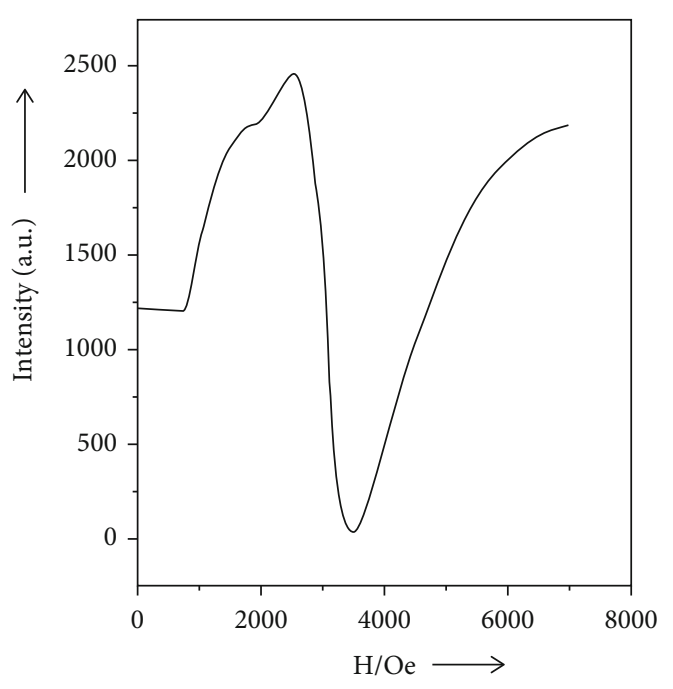

(b)

Figure 8: $\mathrm{M}$ versus $\mathrm{H}$ curves for $\mathrm{Fe}_{2} \mathrm{O}_{3}$ nanoparticles and $\mathrm{Fe}_{3} \mathrm{C}$ MWCNT [133].

AC-COOH embedded in PES- $\mathrm{NH}_{2}$

Acid red 1 dye

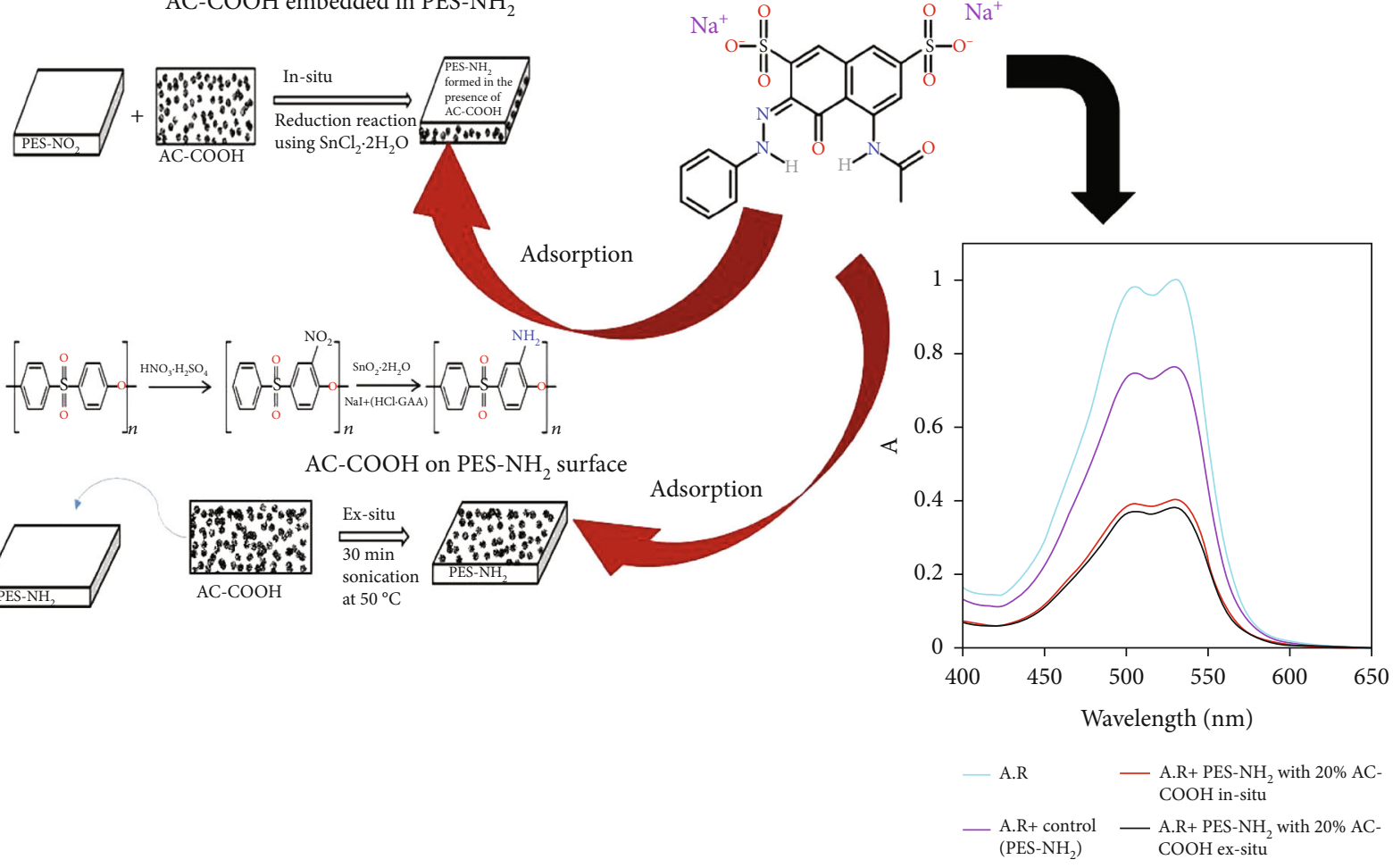

Figure 9: Nanocomposite based on active carbon [142].

deterioration temperature has decreased to $4^{\circ} \mathrm{C}$, which may improve to $3^{\circ} \mathrm{C}$ by the highest degradation temperature [138]. For pure PSF and its nanocomposites, Tg values measured with differential calorimetry scanners are almost comparable. The nanocomposite elasticity modulus exhibits a 17 percent increase in the clean PSF [139]. With the addition of the fillers, the water contact angle revealed a reduction in the hydrophilicity of the composite. In contrast to the nanocom- posite, the carbon dioxide sorbent capacity shows an increase of about $10 \%$ [140]. With the injection of $20 \mathrm{wt}$ percent metal-carbonized filler, the ferromagnetic behaviour of a thermoplastic nanocomposite was observed. Extraordinary magnetic characteristics make it attractive in many industrial applications for a thermoplastic polymer such as polysulfone [141]. The applications of activated carbon for are shown in Table 3. 
TABle 3: Applications of activated carbon [145].

\begin{tabular}{lcc}
\hline Types of AC & Shape/particle size & Application \\
\hline Powder AC (fine powder) & Pulverized carbon/less than $0.18 \mathrm{~mm}$ & Recovery of liquid and gas \\
Granular AC (coarse particles) & Irregular shaped/0.6-4.0 mm & Recovery, separation of liquid and gas \\
Extruded AC (cylindrical particles) & Cylindrical shaped/large than $4.0 \mathrm{~mm}$ & Natural gas storage, off-gases from \\
& wastewater control \\
Activated carbon fiber (threadlike piece) & Fabrication flexibility/narrower pore & Removal of volatile organic compound \\
Activated carbon cloths & size compound distribution & Removal of volatile organic compound \\
\hline
\end{tabular}

A chemical binding on activated carbon powder (AC) nanoparticles was used for synthesising the magnetic $\mathrm{Fe}_{3} \mathrm{O}_{4}$ activated carbon nanocomposites with high surface area as recovered adsorbents [143]. In this nanocomposite, the component $\mathrm{AC}$ and $\mathrm{Fe}_{3} \mathrm{O}_{4}$ are amorphous nongraphic and cubic crystal structure each. Superparamagnetic characteristics were detected in all composite samples. $\mathrm{Fe}_{3} \mathrm{O}_{4}$ AC nanocomposite magnetised saturation was considerably less than that of bare $\mathrm{Fe}_{3} \mathrm{O}_{4}$ particles, showing that the $\mathrm{AC}$ was really bound to $\mathrm{Fe}_{3} \mathrm{O}_{4}$. The picture of the microstructure showed $\mathrm{Fe}_{3} \mathrm{O}_{4}$ particles were spread evenly throughout AC surfaces and hence kept a highly specific surface area. Methyl orange (MO) somewhat decreased its adsorption capacity at $30^{\circ} \mathrm{C}$ from $384 \mathrm{mg} / \mathrm{g}$ for AC ponding to $324 \mathrm{mg} / \mathrm{g}$ for $\mathrm{Fe}_{3} \mathrm{O}_{4} / \mathrm{C}$, a reduction of 15 percent following magnet manufacturing. On $\mathrm{Fe}_{3} \mathrm{O}_{4} / \mathrm{AC}$ nanocomposites, $\mathrm{MO}$ adsorption was shown to follow the pseudosecond-order kinetic model and Langmuir models could describe the isotherm. The simple recovery of magnetic adsorbents from water proved their use potential for eliminating harmful contaminants in the treatment of waste water [144].

3.5. Nanodiamonds. Nanodiamonds offer outstanding mechanical and optical characteristics and are adjustable to the surface. They are also nontoxic, making them suitable for biomedical uses. Nanodiamonds are made from explosive molecules that offer carbon source and conversion energy [146]. The approach for the disposal of obsolete weapons such as composition $\mathrm{B}$, while other explosives may also be employed, is ecologically and economically feasible. The detonation occurs in a confined chamber with a "dry" or "wet" synthesis, or inert gas or water (ice) as shown in Figure 10 [147]. The resulting product soot exposure is a $4-5 \mathrm{~nm}$ diamond combination with various carbohydrates and contaminants. Depending on cooling medium, the carbon output is $4-10 \%$ of the weight of the explosive, during that explosion Danilenko found the formation of nanodiamonds [148]. Bouget's pressures and heat are not sufficiently enough to make liquid carbon in bulk, but are high enough to generate nanoscale liquid carbon. The liquid carbon area is moved to lower nanocarbon temperatures, while the nanodiamond region is moved slightly into higher pressures. It is therefore hypothesised that nanodiamonds develop via the condensation and crystallization of the liquid carbon in volume of the super saturated carbon vapour [149]. Other approaches (such the use of shock waves to generate graphite nanodiamonds) yield crystallite-sized nanodiamonds of more than $10 \mathrm{~nm}$. The soot detonation, apart from the diamonds phase, includes both graphics (25\%-80\% wt) and incombustible impurities (1\%-8\% metals and oxides). The distinctive property of nanodiamonds is that many different functional groups are bonded to their surface compared to carbon nanotubes and other graphic nanoparticles, thereby permitting advanced surface functionality without sacrificing the beneficial characteristics of the diamond core [150].

However, it is equally important to understand how these groups interact with their environment and minimize harmful consequences (such as aggregation). While commercial nanodiamond powders may be utilised for the covalent functionality of different functional groups, the usage of air purification or ozone-generated carboxylated nanodiamonds and then the rich chemistry of $\mathrm{COOH}$ groups are more easy to start with. Nanodiamond is a good filler for composites due to its superior mechanical and thermal characteristics and the rich surface chemical properties of diamond nanoscale particles. The diamond core's biocompatibility and chemical stability make them extremely suitable for biomedical use. The addition of tiny quantities of nanodiamond generated transparent polyvinyl alcohol nanocomposites with enhanced mechanical characteristics [152]. Surface chemistry can influence the interactions between the nanoparticles of the diamonds and the matrix, as well as the dispersion of the nanoparticles in the matrix. Table 4 shows the biomedical applications of nanodiamond composites.

\section{Industrial Applications of Carbon Nanocomposites}

4.1. Super Capacitors. As an electricity collection system, super condenser finds desirable applications in consumer product and alternative energy sources due to its increased energy density, rapid discharge and charge time, lower heating, protection, long-term operating reliability, and no removable components [154]. In particular, CNTs are desirable electrode resources for the production of highperformance super condensers due to its innovative characteristics of high conductivity, high specific volume, high charging power, high mesoporosity, and high electrolyte functionality [155]. These are an appealing choice for applications for energy storage in compact or remote devices [156] where electrodes and traditional condensers must be overdimensioned due to unfavourable power-to-energy ratio [157]. Carbon aerogel (CA) or any other types of carbon 


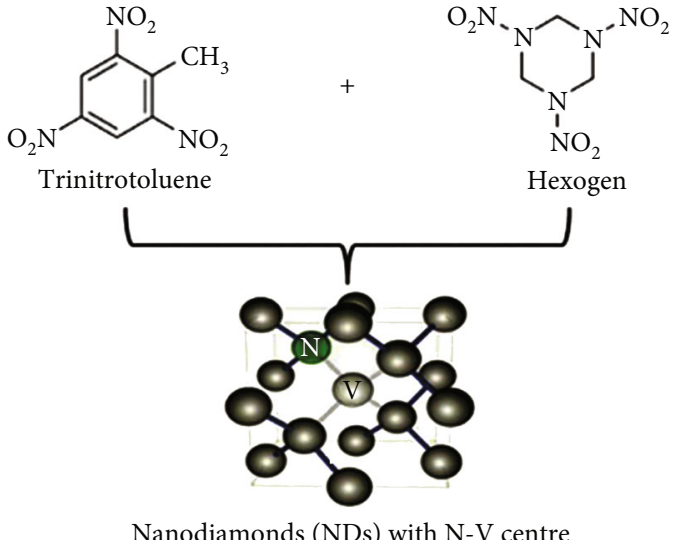

FIgURE 10: Synthesis of nanodiamond [151].

products such as black carbon or carbon cloth are commonly used in these super condensers [158]. Two essential parts for a CNT super capacitor are the electrodes and the electrolyte [159]. Capacity of traditional carbon electrodes will slowly decrease as current discharge density increases [160]. Specific capacitance of nanocomposite electrode with-grown single-walled CNTs, pure PPY, and singlewalled CNT-polypyrrole (PPY) is a result of discharged current densities [161].

The performance of today's super capacitors in terms of power density must be significantly increased, yet maintaining a long life cycle to satisfy the demanding demands of electric hybrid and large-scale industry applications [162]. In order to increase the efficiency of supercapacitors, nanocarbon materials from first generation are employed as electrode materials. MWCNTs as electrodes are in regular, box-like form, with a capacitance up to 120 FG1 and a pure electrostatic attraction characteristic (the value depends on the scanning rate). A gravimetric capacitance of 20 to $300 \mathrm{~F} / \mathrm{g}$ is displayed for EDLCs with a SWCNT electrode. Graphene-processed supercapacitors do not improve performance considerably. The biggest drawback for super capacitors is the limited specific surface area of such nanocarbons [163].

4.2. Biosensors. The integration of observable traits into analytical instruments, particularly in medical research, is becoming a prerequisite for early detection of various diseases [164]. Carbon nanotubes (CNTs) are pseudoonedimensional carbon allotropes, especially identified as a system of carbon atoms arranged into one or more levels of smooth cylinders with either open or closed edges [165]. CNTs have quite wide specific surface area which enables for the immobilization of a substantial number of operational units such as biosensing receptor moieties [166]. CNTs possess special optical intrinsic properties such as near-infrared photoluminescence (NIR) [167]. The biocompatibility and biodegradability were increased by turning the layer of pristine CNTs into hydrophilic f-CNTs [168]. Such biosensors analyse a broad variety of genetic markers of cancer by conjugating DNA or proteins, peptides, enzymes [169], and electrochemical biosensors for the early diagnosis of genetic markers of cancer [170]. Microspecificity of the enzymatic reaction is used by CNT-based enzymatic electrochemical nanomaterials to guide electrical transfer among biomolecules [171]. CNT paste was produced of brumoform, and the electrode was designed with superior enactment over all other carbon electrodes [172]. Bioaffinity electrochemical biosensors are very robust complexes [173] in CNT-DNA electrochemical biosensors have been designed to acquire a simple, cheap, fast sensor [174]. Figure 11 shows the applications of biosensors from nanocomposite. For example, the synthesis of 3-methoxy phenol sensor used for biotech applications made from $\mathrm{Fe}_{3} \mathrm{O}_{4}$. CNT NCs/GCE, and its calculation is shown in Table 5.

Although the study of carbon nanotubes in biological applications is still in its early stages, it has enormous potential. Carbon is a particularly biocompatible substance since it makes up a large portion of the human body [176]. Cell growth on CNTs has been proven; hence, they do not appear to be harmful. The cells also do not attach to the CNTs, which opens the door to uses such as antifouling coatings for ships and prosthetic coatings [177]. The ability to functionalize (chemically alter) the sidewalls of carbon nanotubes (CNTs) opens the door to biological applications such as neuron development and regeneration and vascular stents. It has also been shown that a single strand of DNA may be linked to a nanotube and then efficiently implanted into a cell [178].

4.3. Solar Cells. A new type of solar cell, dye-sensitized solar cells (DSSCs), based on nanocrystalline $\mathrm{TiO} 2$ electrodes, has captured the attention of industry and academia [179]. DSSCs offer lower manufacturing costs relative to commercial silicon-based solar cells and provide similar advantages for amorphous silicon solar cells [180]. CNTs will have a possible high-field direction that interpenetrates DSSC electrodes along. The hypothesis was that carbon nanotubes would effectively increase the electrode's electrical conductivity and thus improve the solar system's light conversion performance [181]. Due to extreme CNT aggregation [182], the expansion of the CNT charge will impair the efficiency of DSSC cells. Dye-sensitized solar cells (DSCs) consisting of colouring molecules, nanocrystalline metal oxides, and natural liquid electrolytes have valuable highperformance characteristics in energy conversion and low energy and manufacturing costs [183]. The carbon cloth (CC) altered MWCNT- $\mathrm{MnO}_{2} / \mathrm{PPy}$ nanocomposite electrode has a good biocompatibility resulting in a well-recognized moderator for the production of bioelectricity in wastewater with less MFCs [184]. Microbial fuel cells (MFCs) generate electricity for the oxidation of organic materials such as acetate, lactate, and glucose from exo electrogenic substances [185]. MFCs have applications in the fields of renewable energy recovery, remotely controlled power supplies, nanomaterials and biofilm testing, hydrogen production, and chemical fermentation systems due to their flexibility in processing various bacterial sources [186].

4.4. Radar Absorbing Materials. The curiosity in radarabsorbing materials (RAM) has extended to the business 
TABLE 4: Biomedical applications of nanodiamonds [153].

\begin{tabular}{|c|c|c|c|}
\hline Nanodiamond kind & System & Cells & Toxicity \\
\hline $\begin{array}{l}\text { Fluorescent nanodiamonds } \\
\text { prepared by detonation } \\
\text { method }\end{array}$ & $\begin{array}{l}\text { Fluorescence nanodiamond } \\
\text { PCL fibers }\end{array}$ & Human lens epithelial cell line & $\begin{array}{l}\text { Nontoxic and the scaffold can } \\
\text { support in vitro cell growth }\end{array}$ \\
\hline Nanodiamonds & Particle & Hepatocyte cells & Nontoxic less than $10 \mu \mathrm{g} \mathrm{ml}$ \\
\hline Nanodiamonds & Particle & $\begin{array}{l}\text { Lymphocytes and cervical } \\
\text { cancer cells in vitro }\end{array}$ & Toxic \\
\hline Nanodiamonds & Particle & $\begin{array}{l}\text { Three kinds of mammalian } \\
\text { cells }\end{array}$ & $\begin{array}{l}\text { It is possible an effect in } \\
\text { noncovalent } \\
\text { adsorption between NDs and serum } \\
\text { proteins in culture medium }\end{array}$ \\
\hline Nanodiamonds & $\begin{array}{l}\text { Natural polymers-BG composite } \\
\text { coating by electrophoretic } \\
\text { deposition }\end{array}$ & Human osteosarcoma cell line & Improving cellular behaviour \\
\hline
\end{tabular}

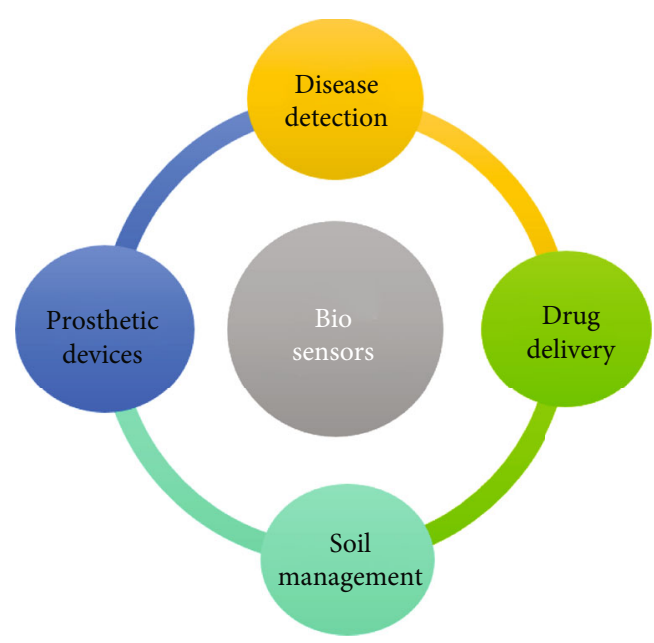

FIgURE 11: Applications of biosensors from nanocomposite.

sector as they can be used to minimize electromagnetic interference due to recent developments in electromagnetic devices entering the RF frequency range [187]. Short carbon fiber reinforced composites (CFRC) are ideally suited for the development of thin multipurpose RAM [188]. Owing to their high execution of electrical and thermal qualities at comparatively low concentration, composites dependent on polymers and carbon nanofillers have received significant interest in both academic and industrial societies [189]. Extraordinary interest has been given to carbon nanostructure-filled polymer nanocomposites as electromagnetic absorbers in both military and civil applications [190] in terms of their ability to modify electromagnetic and molecular properties at comparatively low quantities of nanofiller extraordinary interest has been given to carbon nanostructure-filled polymer nanocomposites as electromagnetic absorbers in both military and civil applications [191] in terms of their ability to modify electromagnetic and molecular properties at comparatively low quantities of nanofillers and their light weight, outstanding thermal tolerance and high mechanical characteristics and their light weight, and outstanding thermal tolerance and high mechanical characteristics [192].
4.5. Energy Storage. The intrinsic characteristics of CNT make them two fast-growing technologies the ideal material to be used as electrodes in condensers and batteries. The electrical conductivity of CNTs is high, and their area of exceptionally high surface $\left(\sim 1000 \mathrm{~m}^{2} / \mathrm{g}\right)$ is particularly accessible to the electrolyte because of their linear geometries. Research has shown that CNTs have the largest reversible capacity for usage in lithium-ion batteries with any carbon material [193]. In addition, the CNTs are ideal materials for electrodes with supercapacitors and are readily available for sale. Moreover, CNTs are used in several components of the fuel cell. They have various features, such as high thermal conductivity and surface area, and are important in PEM fuel cells as electrode catalyst support [194]. They also may be utilised in gas diffusion layers, in addition to current collectors, due to their high electrical capacity [195]. CNTs are also able to demonstrate great strength and toughness to weight as part of composites in fuel cells that are utilised in transportation applications where durability is essential [196].

4.6. Field Emission Applications. CNTs are the best-known source of any substance in the area. It is comprehensible because of its great electrical performance and the incredible sharpness of its tip (when the curvature radius of the tip is reduced, the electric area will be concentrated, resulting in enhanced emissions from the field, this is because of the sharp lightning rods) [197]. Moreover, the sharpness of the tip also suggests that they emit at a very low voltage, which is a critical attribute for creating low-power electrical devices [198]. CNTs may be quite current, perhaps up to 1013 $\mathrm{A} / \mathrm{cm}^{2}$. CNT's are very high. The current is also quite steady. This characteristic is implemented immediately and attracts great interest in field-emission flat panel displays. CNTbased displaying uses a distinct electron gun (or perhaps several of them) for every pixel in the view, as opposed to traditional cathode ray tube display with a single electron gun [199]. CNTs have low turn-off and operating voltages, a large current density, and constant, long-lived behaviour, which make this application highly desirable. Other applications using CNT's field emission properties are general low- 
TABLE 5: Calculation of 3-methoxy phenol sensor with $\mathrm{Fe}_{3} \mathrm{O}_{4}$. CNT NCs/GCE [175].

\begin{tabular}{lcccccc}
\hline \multirow{2}{*}{ Samples } & \multicolumn{2}{c}{ Observed current $(\mu \mathrm{A})$} & Conc. $(\mu \mathrm{M})$ & SD $(n=3)$ \\
\hline Industrial effluent & $\mathrm{R} 1$ & $\mathrm{R} 2$ & $\mathrm{R} 3$ & Average & 5.75 & 23.76 \\
PC baby bottle & 7.09 & 5.27 & 4.91 & 5.80 & 23.96 & 1.17 \\
PC bottle & 7.73 & 5.25 & 4.42 & 3.22 & 13.30 & 1.72 \\
PVC food packaging bag & 1.66 & 4.14 & 3.85 & 3.34 & 14.09 & 1.36 \\
Red sea water & 4.18 & 3.08 & 2.77 & 3.41 & 0.74 & 0.88 \\
Tape water & 4.33 & 3.31 & 2.58 & 2,83 & 0.63 \\
\hline
\end{tabular}

voltage cold cathode light sources, electron microscope sources, and lightning arresters [200].

4.7. Conductive Plastic. Plastics have been used in many cases as a metal replacement. Polymers have improved enormously for structural applications but not where electrical conductivity is essential, as plastics are particularly strong electrical insulators [201]. The filling of polymers with lever fillers like as carbon black and bigger graphite fibers can prevent this deficit (the ones used to make golf clubs and tennis rackets) [202]. However, the loading needed is generally considerable, resulting in hefty parts and plastic parts which have a high degraded construction characteristic, in order to give the requisite conductivity via traditional fillers [203]. As the load needed for a certain conductivity is reduced as the filling particle aspect ratio is higher. For this reason, CNT is excellent since it has the greatest carbon fiber aspect ratio. In addition, their intrinsic inclination to shape cords provides naturally very lengthy leading routes even at extremely low loads [204]. This characteristic of CNT is used in applications such as electrostatic dissipation (ESD), composite EMI (electromagnetic interference), shielding, gasket, enclosure, and other usage coatings, low-observance radar absorption materials, and conductive (even transparent) antistatic and material coatings [205].

4.8. Future Scope. Significant improvements in the preparation of carbon nanotube-polymer composites with remarkable mechanical and physical characteristics have been achieved. In this area, a great deal of study is still required until these remarkable characteristics are completely realised in a macroscopic nanometric medium. In addition, experiments have to be done in order to identify disintegration or recycling mechanisms for carbon nanocomposites in order to create something new at the end of their life cycle (recycle). Furthermore, research has not progressed much while attempting to produce naturally enhanced compounds using biologically degradable polymer matrix, as the creation of such "green composites" poses a number of obstacles. They are regarded as the most ecologically sound material but issues such as poor adherence to the fiber matrix, difficulty in fiber orientation, and the attainment of nanoscale dimensions halt those materials in search of appropriate applications. In this regard, some limitations include insulating individual nanofiber composites to evaluate the nanofibers tensile characteristics and adhere them to a load tester which is yet difficult. Electro spun nanofiber, atomistic modelling, and continuum mechanism methods remain a major challenge to theoretical approaches in prediction of the mechanical behaviour of CNTs implanted in electro spun fibers.

\section{Conclusion}

Carbon nanocomposites assisted by metal nanoparticles have been observed to perform a substantial role in a broad array of potential applications in science and technologies. In this research work, the prominent enhancements have been made in formulating carbon nanotube polymer composite materials with excellent mechanical and thermodynamic properties are studied. The carbon nanotube functionalization improves the diffusion status of carbon nanotubes and to change the properties of the device and boost the attributes of polymer nanocomposite products, particularly material properties. The incessant demand for the commercial usage of engineered carbon-based nanomaterials is increasing in the field of modern technology, medicine, environment, and agriculture; the distinctive properties of carbon-based nanomaterials have engrossed great concentration by the researchers and industrialists which has stimulated the expansion and innovation techniques for significant industrial production.

(i) The advanced production techniques for carbon nanocomposites (primarily graphene or graphene oxide and CNTs) and their usage in organic processes have been discussed

(ii) Layered nanocomposites are the most widely used materials for increasing the barrier character of polymer nanocomposites in packaging applications

(iii) Nanocomposites also serve as organic photovoltaic sheets in solar panels. These films may be utilised as flexible semitransparent modules and are exceptionally light in weight. The other advantages of these films are continuous production for different light and climatic conditions

(iv) Nanocomposites based on graphene oxide (GO) can make a substantial contribution to the treatment of waste water by removing heavy metals 
(v) Due to characteristics such as long-term durability, better sensitivity, stronger order conductivity, and easy production, carbon nanocomposites are used in construction of sensors

\section{Conflicts of Interest}

The author(s) declare(s) that they have no conflicts of interest.

\section{References}

[1] N. M. Julkapli and S. Bagheri, "Graphene supported heterogeneous catalysts: an overview," International Journal of Hydrogen Energy, vol. 40, no. 2, pp. 948-979, 2015.

[2] D. Deng, L. Xiao, I.-M. Chung, I. S. Kim, and M. Gopiraman, "Industrial-quality graphene oxide switched highly efficient Metal- and solvent-free synthesis of $\beta$-ketoenamines under feasible conditions," ACS Sustainable Chemistry \& Engineering, vol. 5, no. 2, pp. 1253-1259, 2017.

[3] O. Zaytseva and G. Neumann, "Carbon nanomaterials: production, impact on plant development, agricultural and environmental applications," Chemical and Biological Technologies in Agriculture, vol. 3, no. 1, p. 17, 2016.

[4] P. O'Brien, R. Nuzzo, H. Kroto, and J. Rocha, Hierarchical nanostructures for energy devices, Royal Society of Chemistry, 2014.

[5] B. C. Yadav and R. Kumar, "Structure, properties and applications of fullerenes," International Journal of Nanotechnology and Applications, vol. 2, no. 1, pp. 15-24, 2008.

[6] R. Taylor and D. R. M. Walton, "The chemistry of fullerenes," Nature, vol. 363, no. 6431, pp. 685-693, 1993.

[7] R. Zhang, Y. Zhang, Q. Zhang, H. Xie, W. Qian, and F. Wei, "Growth of half-meter long carbon nanotubes based on Schulz-Flory distribution," ACS Nano, vol. 7, no. 7, pp. 6156-6161, 2013.

[8] A. M. K. Esawi, K. Morsi, A. Sayed, M. Taher, and S. Lanka, "Effect of carbon nanotube (CNT) content on the mechanical properties of CNT- reinforced aluminium composites," Composites Science and Technology, vol. 70, no. 16, pp. 2237-2241, 2010.

[9] X.-M. Liu, Z. Huang, S. Oh et al., "Carbon nanotube (CNT)based composites as electrode material for rechargeable Liion batteries: a review," Composites Science and Technology, vol. 72, no. 2, pp. 121-144, 2012.

[10] R. Khare and S. Bose, "Carbon nanotube based composites-a review," Journal of Minerals and Materials Characterization and Engineering, vol. 4, no. 1, pp. 31-46, 2005.

[11] W. Krätschmer, "The story of making fullerenes," Nanoscale, vol. 3, no. 6, pp. 2485-2489, 2011.

[12] K. Morsi and A. Esawi, "Effect of mechanical alloying time and carbon nanotube (CNT) content on the evolution of aluminum (Al)-CNT composite powders," Journal of Materials Science, vol. 42, no. 13, pp. 4954-4959, 2007.

[13] S. H. Chae and Y. H. Lee, "Carbon nanotubes and graphene towards soft electronics," Nano Convergence, vol. 1, no. 1, pp. 1-26, 2014.

[14] M. F. L. de Volder, S. H. Tawfick, R. H. Baughman, and A. J. Hart, "Carbon nanotubes: present and future commercial applications," science, vol. 339, no. 6119, pp. 535-539, 2013.
[15] K. Ahmad and W. Pan, "Microstructure-toughening relation in alumina based multiwall carbon nanotube ceramic composites," Journal of the European Ceramic Society, vol. 35, no. 2, pp. 663-671, 2015.

[16] X. Zang, Q. Zhou, J. Chang, Y. Liu, and L. Lin, "Graphene and carbon nanotube (CNT) in MEMS/NEMS applications," Microelectronic Engineering, vol. 132, pp. 192-206, 2015.

[17] A. K. Geim and K. S. Novoselov, "The rise of graphene," Nature Mater. 6., vol. 183, no. 2007, p. 109, 2010.

[18] M. Kang, M. W. Song, and C. H. Lee, "Catalytic carbon monoxide oxidation over $\mathrm{CoO}_{\mathrm{x}} / \mathrm{CeO}_{2}$ composite catalysts," Applied Catalysis A: General, vol. 251, no. 1, pp. 143-156, 2003.

[19] D. Vairavapandian, P. Vichchulada, and M. D. Lay, "Preparation and modification of carbon nanotubes: review of recent advances and applications in catalysis and sensing," Analytica Chimica Acta, vol. 626, no. 2, pp. 119-129, 2008.

[20] D. S. Su and R. Schlögl, "Nanostructured carbon and carbon nanocomposites for electrochemical energy storage applications," ChemSusChem: Chemistry \& Sustainability Energy \& Materials, vol. 3, no. 2, pp. 136-168, 2010.

[21] R. J. Chen, S. Bangsaruntip, K. A. Drouvalakis et al., "Noncovalent functionalization of carbon nanotubes for highly specific electronic biosensors," Proceedings of the National Academy of Sciences, vol. 100, no. 9, pp. 4984-4989, 2003.

[22] Y.-L. Zhao and J. F. Stoddart, "Noncovalent functionalization of single-walled carbon nanotubes," Accounts of chemical research, vol. 42, no. 8, pp. 1161-1171, 2009.

[23] J. Zhao, J. P. Lu, J. Han, and C.-K. Yang, "Noncovalent functionalization of carbon nanotubes by aromatic organic molecules," Applied Physics Letters, vol. 82, no. 21, pp. 3746-3748, 2003.

[24] V. Georgakilas, J. N. Tiwari, K. C. Kemp et al., "Noncovalent functionalization of graphene and graphene oxide for energy materials, biosensing, catalytic, and biomedical applications," Chemical Reviews, vol. 116, no. 9, pp. 5464-5519, 2016.

[25] N. Nakayama-Ratchford, S. Bangsaruntip, X. Sun, K. Welsher, and H. Dai, "Noncovalent functionalization of carbon nanotubes by fluorescein- polyethylene glycol: supramolecular conjugates with $\mathrm{pH}$-dependent absorbance and fluorescence," Journal of the American Chemical Society, vol. 129, no. 9, pp. 2448-2449, 2007.

[26] J. Chen and C. P. Collier, "Noncovalent functionalization of single-walled carbon nanotubes with water-soluble porphyrins," The Journal of Physical Chemistry B, vol. 109, no. 16, pp. 7605-7609, 2007.

[27] P. Petrov, F. Stassin, C. Pagnoulle, and R. Jérôme, "Noncovalent functionalization of multi-walled carbon nanotubes by pyrene containing polymers," Chemical Communications, vol. 23, no. 23, pp. 2904-2905, 2003.

[28] A. Ghosh, K. . V. Rao, S. . J. George, and C. . N. . R. Rao, "Noncovalent functionalization, exfoliation, and solubilization of graphene in water by employing a fluorescent coronene carboxylate," Chemistry-A European Journal, vol. 16, no. 9, pp. 2700-2704, 2010.

[29] R. Tian, X. Jia, J. Yang, Y. Li, and H. Song, "Large-scale, green, and high-efficiency exfoliation and noncovalent functionalization of fluorinated graphene by ionic liquid crystal," Chemical Engineering Journal, vol. 395, article 125104, 2020.

[30] J. Kim, J. Cha, B. Chung, S. Ryu, and S. H. Hong, "Fabrication and mechanical properties of carbon fiber/epoxy nanocomposites containing high loadings of noncovalently 
functionalized graphene nanoplatelets," Composites Science and Technology, vol. 192, article 108101, 2020.

[31] N. Alzate-Carvajal, L. M. Bolivar-Pineda, V. Meza-Laguna, V. A. Basiuk, E. V. Basiuk, and E. A. Baranova, "Oxygen evolution reaction on single-walled carbon nanotubes noncovalently functionalized with metal phthalocyanines," ChemElectroChem, vol. 7, no. 2, pp. 428-436, 2020.

[32] Z. Ju, X. Yao, Z. Luo, M. Cao, and W. Xiao, “Theoretical studies on the noncovalent interaction of fructose and functionalized ionic liquids," Carbohydrate Research, vol. 487, article 107882, 2020.

[33] M. Karimi, N. Solati, M. Amiri et al., "Carbon nanotubes part I: preparation of a novel and versatile drug-delivery vehicle," Expert opinion on drug delivery, vol. 12, no. 7, pp. 1071-1087, 2015.

[34] R. S. Ribeiro, A. M. T. Silva, J. L. Figueiredo, J. L. Faria, and H. T. Gomes, "Catalytic wet peroxide oxidation: a route towards the application of hybrid magnetic carbon nanocomposites for the degradation of organic pollutants. A review," Applied Catalysis B: Environmental, vol. 187, pp. 428-460, 2016.

[35] X. Zhou, Z. Dai, J. Bao, and Y.-G. Guo, "Wet milled synthesis of an $\mathrm{Sb} / \mathrm{MWCNT}$ nanocomposite for improved sodium storage," Journal of Materials Chemistry A, vol. 1, no. 44, pp. 13727-13731, 2013.

[36] S. H. S. Zein, L.-C. Yeoh, S.-P. Chai, A. R. Mohamed, and M. E. M. Mahayuddin, "Synthesis of manganese oxide/carbon nanotube nanocomposites using wet chemical method," Journal of materials processing technology, vol. 190, no. 1-3, pp. 402-405, 2007.

[37] M. N. Rumyantseva, V. V. Kovalenko, A. M. Gaskov et al., "Nanocomposites $\mathrm{SnO}_{2} / \mathrm{Fe}_{2} \mathrm{O}_{3}$ : wet chemical synthesis and nanostructure characterization," Sensors and Actuators B: Chemical, vol. 109, no. 1, pp. 64-74, 2005.

[38] Y. Zhou, Y. Fang, and R. P. Ramasamy, "Non-covalent functionalization of carbon nanotubes for electrochemical biosensor development," Sensors, vol. 19, no. 2, p. 392, 2019.

[39] K. Shameli, M. B. Ahmad, W. Z. Yunus, N. A. Ibrahim, and M. Darroudi, "Synthesis and characterization of silver/talc nanocomposites using the wet chemical reduction method," International journal of nanomedicine, vol. 5, p. 743, 2010.

[40] C. Chae, K. W. Kim, S. J. Kim et al., "3D intra-stacked CoO/carbon nanocomposites welded by Ag nanoparticles for highcapacity, reversible lithium storage," Nanoscale, vol. 7, no. 23, pp. 10368-10376, 2015.

[41] J. Dong, W. Liu, H. Li, X. Su, X. Tang, and C. Uher, "In situ synthesis and thermoelectric properties of $\mathrm{PbTe}$-graphene nanocomposites by utilizing a facile and novel wet chemical method," Journal of Materials Chemistry A, vol. 1, no. 40, pp. 12503-12511, 2013.

[42] W.-C. Du, Y.-X. Yin, X.-X. Zeng et al., "Wet chemistry synthesis of multidimensional nanocarbon-sulfur hybrid materials with ultrahigh sulfur loading for lithium-sulfur batteries," ACS Applied Materials \& Interfaces, vol. 8, no. 6, pp. 3584-3590, 2016.

[43] S. Yogeshwaran, L. Natrayan, G. Udhayakumar, G. Godwin, and L. Yuvaraj, "Effect of waste tyre particles reinforcement on mechanical properties of jute and abaca fiber-epoxy hybrid composites with pre-treatment," Materials Today: Proceedings, vol. 37, no. 2, pp. 1377-1380, 2021.
[44] S. Li, Y. Wang, C. Lai et al., "Directional synthesis of tin oxide@ graphene nanocomposites via a one-step upscalable wet-mechanochemical route for lithium ion batteries," Journal of Materials Chemistry A, vol. 2, no. 26, pp. 10211-10217, 2014.

[45] M. Jeyaraj, S. Gurunathan, M. Qasim, M.-H. Kang, and J.H. Kim, "A comprehensive review on the synthesis, characterization, and biomedical application of platinum nanoparticles," Nanomaterials, vol. 9, no. 12, p. 1719, 2019.

[46] R. Ramachandran, M. Saranya, A. N. Grace, and F. Wang, "MnS nanocomposites based on doped graphene: simple synthesis by a wet chemical route and improved electrochemical properties as an electrode material for supercapacitors," $R S C$ advances, vol. 7, no. 4, pp. 2249-2257, 2017.

[47] M. Gich, C. Fernández-Sánchez, L. C. Cotet, P. Niu, and A. Roig, "Facile synthesis of porous bismuth-carbon nanocomposites for the sensitive detection of heavy metals," Journal of Materials Chemistry A, vol. 1, no. 37, pp. 11410-11418, 2013.

[48] L. Gan, S. Shang, C. Mei, L. Xu, L. Tan, and E. Hu, "Wet functionalization of carbon nanotubes and its applications in rubber composites," Carbon-Based Nanofillers and Their Rubber Nanocomposites, vol. 3, pp. 77-108, 2019.

[49] S. A. Mirzaee, N. Jaafarzadeh, H. T. Gomes, S. Jorfi, and M. Ahmadi, "Magnetic titanium/carbon nanotube nanocomposite catalyst for oxidative degradation of Bisphenol A from high saline polycarbonate plant effluent using catalytic wet peroxide oxidation," Chemical Engineering Journal, vol. 370, pp. 372-386, 2019.

[50] G. Pandey, D. Rawtani, and Y. K. Agrawal, "Aspects of nanoelectronics in materials development," in Nanoelectronics and Materials Development, IntechOpen, 2016.

[51] H.-W. Tien, Y.-L. Huang, S.-Y. Yang, J.-Y. Wang, and C. C. M. Ma, "The production of graphene nanosheets decorated with silver nanoparticles for use in transparent, conductive films," Carbon, vol. 49, no. 5, pp. 1550-1560, 2011.

[52] N. Yang, S. Zhu, D. Zhang, and S. Xu, "Synthesis and properties of magnetic $\mathrm{Fe}_{3} \mathrm{O}_{4}$-activated carbon nanocomposite particles for dye removal," Materials Letters, vol. 62, no. 4-5, pp. 645-647, 2008.

[53] S. E. A. S. El-Deen and F. Zhang, "Synthesis of [email protected] Nanocomposite for the Recovery of as (V) from Wastewater," Procedia Environmental Sciences, vol. 16, pp. 378-390, 2012.

[54] A. Ślosarczyk, M. Barełkowski, S. Niemier, and P. Jakubowska, "Synthesis and characterisation of silica aerogel/carbon microfibers nanocomposites dried in supercritical and ambient pressure conditions," Journal of Sol-Gel Science and Technology, vol. 76, no. 1, pp. 227-232, 2015.

[55] T.-H. Ko, S. Radhakrishnan, M.-K. Seo, M.-S. Khil, H.Y. Kim, and B.-S. Kim, "A green and scalable dry synthesis of $\mathrm{NiCo}_{2} \mathrm{O}_{4} /$ graphene nanohybrids for high-performance supercapacitor and enzymeless glucose biosensor applications," Journal of Alloys and Compounds, vol. 696, pp. 193200, 2017.

[56] S.-L. Chou, J.-Z. Wang, H.-K. Liu, and S.-X. Dou, "Rapid synthesis of Li4Ti5O12Microspheres as anode materials and its binder effect for lithium-ion battery," The Journal of Physical Chemistry C, vol. 115, no. 32, pp. 16220-16227, 2011.

[57] S. Kalathil, M. M. Khan, A. N. Banerjee, J. Lee, and M. H. Cho, "A simple biogenic route to rapid synthesis of Au@ 
TiO 2 nanocomposites by electrochemically active biofilms," Journal of Nanoparticle Research, vol. 14, no. 8, p. 1051, 2012.

[58] S. Kellici, J. Acord, A. Vaughn et al., "Calixarene assisted rapid synthesis of silver-graphene nanocomposites with enhanced antibacterial activity," ACS Applied Materials \& Interfaces, vol. 8, no. 29, pp. 19038-19046, 2016.

[59] P. Nguyen-Tri, T. A. Nguyen, P. Carriere, and C. Ngo Xuan, "Nanocomposite coatings: preparation, characterization, properties, and applications," International Journal of Corrosion, vol. 2018, Article ID 4749501, 19 pages, 2018.

[60] S. Yogeshwaran, L. Natrayan, S. Rajaraman, S. Parthasarathi, and S. Nestro, "Experimental investigation on mechanical properties of Epoxy/graphene/fish scale and fermented spinach hybrid bio composite by hand lay-up technique," Materials Today: Proceedings, vol. 37, no. 2, pp. 1578-1583, 2021.

[61] V. Vergaro, I. Pisano, R. Grisorio et al., "CaCO3 as an environmentally friendly renewable material for drug delivery systems: uptake of HSA-CaCO3 nanocrystals conjugates in cancer cell lines," Materials, vol. 12, no. 9, p. 1481, 2019.

[62] L. M. G. da Silva, H. G. Lemos, S. F. Santos, R. A. Antunes, and E. C. Venancio, "Polyaniline/carbon black nanocomposites: the role of synthesis conditions on the morphology and properties," Materials Today Communications, vol. 16, pp. 14-21, 2018.

[63] K. H. Wu, Y. C. Chang, C. C. Yang, Y. J. Gung, and F. C. Yang, "Synthesis, infrared stealth and corrosion resistance of organically modified silicate-polyaniline/carbon black hybrid coatings," European Polymer Journal, vol. 45, no. 10, pp. 2821-2829, 2009.

[64] E. Esmizadeh, G. Naderi, and S. M. R. Paran, "Preparation and characterization of hybrid nanocomposites based on NBR/nanoclay/carbon black," Polymer Composites, vol. 38, pp. E181-E188, 2017.

[65] K. H. Wu, T. H. Ting, G. P. Wang, W. D. Ho, and C. C. Shih, "Effect of carbon black content on electrical and microwave absorbing properties of polyaniline/carbon black nanocomposites," Polymer Degradation and Stability, vol. 93, no. 2, pp. 483-488, 2008.

[66] S. Tolooei, G. Naderi, S. Shokoohi, and S. Soltani, "Elastomer nanocomposites based on NBR/BR/nanoclay: morphology and mechanical properties," Journal of Polymer Engineering, vol. 33, no. 2, pp. 133-139, 2013.

[67] S. H. Jafari, A. Asadinezhad, A. K. Vahid, H. A. Khonakdar, U. Wagenknecht, and G. Heinrich, "Polypropylene/poly (trimethylene terephthalate) blend nanocomposite: a thermal properties study," Polymer-Plastics Technology and Engineering, vol. 51, no. 7, pp. 682-688, 2012.

[68] K. Chrissafis, K. M. Paraskevopoulos, S. Y. Stavrev, A. Docoslis, A. Vassiliou, and D. N. Bikiaris, "Characterization and thermal degradation mechanism of isotactic polypropylene/carbon black nanocomposites," Thermochimica Acta, vol. 465, no. 1-2, pp. 6-17, 2007.

[69] T. Liu, S. Jia, T. Kowalewski, K. Matyjaszewski, R. CasadoPortilla, and J. Belmont, "Water-dispersible carbon black nanocomposites prepared by surface-initiated atom transfer radical polymerization in protic media," Macromolecules, vol. 39, no. 2, pp. 548-556, 2006.

[70] Q. Li, Siddaramaiah, N. H. Kim, G.-H. Yoo, and J. H. Lee, "Positive temperature coefficient characteristic and structure of graphite nanofibers reinforced high density polyethylene/carbon black nanocomposites," Composites Part B: Engineering, vol. 40, no. 3, pp. 218-224, 2009.
[71] X. Liu, C. Li, Y. Pan, D. W. Schubert, and C. Liu, "Shearinduced rheological and electrical properties of molten poly(methyl methacrylate)/carbon black nanocomposites," Composites Part B: Engineering, vol. 164, pp. 37-44, 2019.

[72] J. du, Z. Zhang, D. Liu, T. Ren, D. Wan, and H. Pu, "Triple-stimuli responsive shape memory effect of novel polyolefin elastomer/lauric acid/carbon black nanocomposites," Composites Science and Technology, vol. 169, pp. 45-51, 2019.

[73] Z. Li, H. Xu, X. Xia, Y. Song, and Q. Zheng, "Energy dissipation accompanying Mullins effect of nitrile butadiene rubber/carbon black nanocomposites," Polymer, vol. 171, pp. 106-114, 2019.

[74] Z. Chen, J. Hu, J. Ju, and T. Kuang, "Fabrication of poly (butylene succinate)/carbon black nanocomposite foams with good electrical conductivity and high strength by a supercritical CO2 foaming process," Polymers, vol. 11, no. 11, p. 1852, 2019.

[75] T. H. Wu, A. Foyet, A. Kodentsov, L. G. J. van der Ven, R. A. T. M. van Benthem, and G. de With, "Curing and percolation for carbon black-epoxy-amine nanocomposites," Composites Science and Technology, vol. 181, article 107672, 2019.

[76] C. Yan, L. Guo, D. Ren, and P. Duan, "Novel composites based on geopolymer for removal of $\mathrm{Pb}(\mathrm{II})$, , Materials Letters, vol. 239, pp. 192-195, 2019.

[77] V. A. Silva, L. d. C. Folgueras, G. M. Cândido, A. L. de Paula, M. C. Rezende, and M. L. Costa, "Nanostructured composites based on carbon nanotubes and epoxy resin for use as radar absorbing materials," Materials Research, vol. 16, no. 6, pp. 1299-1308, 2013.

[78] C. Zhu, D. Liu, Z. Chen, L. Li, and T. You, “An ultra-sensitive aptasensor based on carbon nanohorns/gold nanoparticles composites for impedimetric detection of carbendazim at picogram levels," Journal of Colloid and Interface Science, vol. 546, pp. 92-100, 2019.

[79] Y.-J. Heo, Y. Zhang, K. Y. Rhee, and S.-J. Park, "Synthesis of PAN/PVDF nanofiber composites-based carbon adsorbents for $\mathrm{CO}_{2}$ capture," Composites Part B: Engineering, vol. 156, pp. 95-99, 2019.

[80] C. G. Robertson and N. J. Hardman, "Nature of carbon black reinforcement of rubber: perspective on the original polymer nanocomposite," Polymers, vol. 13, no. 4, p. 538, 2021.

[81] S. S. Suner, S. Demirci, B. Yetiskin et al., "Cryogel composites based on hyaluronic acid and halloysite nanotubes as scaffold for tissue engineering," International Journal of Biological Macromolecules, vol. 130, pp. 627-635, 2019.

[82] H. Lee, D. Lee, J. Cho et al., "Super-insulating, flame-retardant, and flexible poly(dimethylsiloxane) composites based on silica aerogel," Composites Part A: Applied Science and Manufacturing, vol. 123, pp. 108-113, 2019.

[83] E. Galata, E. A. Georgakopoulou, M.-E. Kassalia, N. Papadopoulou-Fermeli, and E. A. Pavlatou, "Development of smart composites based on doped-TiO2 nanoparticles with visible light anticancer properties," Materials, vol. 12, no. 16, p. 2589, 2019.

[84] A. G. Rosenberger, D. C. Dragunski, E. C. Muniz et al., "Electrospinning in the preparation of an electrochemical sensor based on carbon nanotubes," Journal of Molecular Liquids, vol. 298, article 112068, 2020.

[85] X. Yuan, X. Zhang, L. Sun, Y. Wei, and X. Wei, "Cellular toxicity and immunological effects of carbon-based 
nanomaterials," Particle and Fibre Toxicology, vol. 16, no. 1, pp. 1-27, 2019.

[86] G. R. Mitchell, F. J. Davis, S. Mohan, and M. Nazhipkyzy, "Highly Anisotropic Polymer Composites Based on Carbon Nanotubes," in Carbon Nanotubes-Recent Progress, IntechOpen, 2017.

[87] F. Inam, D. W. Y. Wong, M. Kuwata, and T. Peijs, "Multiscale hybrid micro-nanocomposites based on carbon nanotubes and carbon fibers," Journal of Nanomaterials, vol. 2010, Article ID 453420, 12 pages, 2010.

[88] A. Eatemadi, H. Daraee, H. Karimkhanloo et al., "Carbon nanotubes: properties, synthesis, purification, and medical applications," Nanoscale Research Letters, vol. 9, no. 1, p. 393, 2014.

[89] M. S. Dresselhaus, G. Dresselhaus, P. C. Eklund, and A. M. Rao, "Carbon nanotubes," in The physics of fullerene-based and fullerene-related materials, pp. 331-379, Springer, Dordrecht, 2000.

[90] G. Dresselhaus, G. Dresselhaus, P. Eklund, and R. Saito, "carbon nanotubes," World scientific, vol. 11, no. 1, pp. 33-38, 1998.

[91] N. Saifuddin, A. Z. Raziah, and A. R. Junizah, "Carbon nanotubes: a review on structure and their interaction with proteins," Journal of Chemistry, vol. 2013, Article ID 676815, 18 pages, 2013.

[92] S. Pattnaik, K. Swain, and Z. Lin, "Graphene and graphenebased nanocomposites: biomedical applications and biosafety," Journal of Materials Chemistry B, vol. 4, no. 48, pp. 7813-7831, 2016.

[93] D. G. Papageorgiou, I. A. Kinloch, and R. J. Young, "Mechanical properties of graphene and graphene-based nanocomposites," Progress in Materials Science, vol. 90, pp. 75-127, 2017.

[94] V. Dhand, K. Y. Rhee, H. Ju Kim, and D. Ho Jung, "A comprehensive review of graphene nanocomposites: research status and trends," Journal of Nanomaterials, vol. 2013, Article ID 763953, 14 pages, 2013.

[95] Y. Liang, D. Wu, X. Feng, and K. Müllen, "Dispersion of graphene sheets in organic solvent supported by ionic interactions," Advanced Materials, vol. 21, no. 17, pp. 1679-1683, 2009.

[96] H. L. Guo, X. F. Wang, Q. Y. Qian, F. Wang, and X. Xia, “A green approach to the synthesis of graphene nanosheets," ACS Nano, vol. 3, no. 9, pp. 2653-2659, 2009.

[97] T. Yamada, J. Kim, M. Ishihara, and M. Hasegawa, "Lowtemperature graphene synthesis using microwave plasma CVD," Journal of Physics D: Applied Physics, vol. 46, no. 6, article 063001, 2013.

[98] G. Williams, B. Seger, and P. V. Kamat, “TiO2-graphene nanocomposites. UV-assisted photocatalytic reduction of graphene oxide," ACS nano, vol. 2, no. 7, pp. 1487-1491, 2008.

[99] R. J. Young, I. A. Kinloch, L. Gong, and K. S. Novoselov, “The mechanics of graphene nanocomposites: a review," Composites Science and Technology, vol. 72, no. 12, pp. 1459-1476, 2012.

[100] K. M. F. Shahil and A. A. Balandin, "Graphene-multilayer graphene nanocomposites as highly efficient thermal interface materials," Nano letters, vol. 12, no. 2, pp. 861-867, 2012.

[101] H.-B. Zhang, W.-G. Zheng, Q. Yan et al., "Electrically conductive polyethylene terephthalate/graphene nanocompos- ites prepared by melt compounding," polymer, vol. 51, no. 5, pp. 1191-1196, 2010.

[102] Y. Li, L. Tang, and J. Li, "Preparation and electrochemical performance for methanol oxidation of Pt/graphene nanocomposites," Electrochemistry Communications, vol. 11, no. 4, pp. 846-849, 2009.

[103] S. Dul, L. Fambri, and A. Pegoretti, "Fused deposition modelling with ABS-graphene nanocomposites," Composites Part A: Applied Science and Manufacturing, vol. 85, pp. 181-191, 2016.

[104] H. P. Bei, Y. Yang, Q. Zhang et al., "Graphene-based nanocomposites for neural tissue engineering," Molecules, vol. 24, no. 4, p. 658, 2019.

[105] Y.-W. Chen, Y. L. Su, S.-H. Hu, and S.-Y. Chen, "Functionalized graphene nanocomposites for enhancing photothermal therapy in tumor treatment," Advanced Drug Delivery Reviews, vol. 105, pp. 190-204, Part B, 2016.

[106] S. N. Tripathi, G. S. S. Rao, A. B. Mathur, and R. Jasra, "Polyolefin/graphene nanocomposites: a review," RSC Advances, vol. 7, no. 38, pp. 23615-23632, 2017.

[107] K. Singh, A. Ohlan, and S. K. Dhaw, "Polymer-graphene nanocomposites: preparation, characterization, properties, and applications," in Nanocomposites-New Trends and Developments, pp. 37-72, IntechOpen, 2012.

[108] H. Sharififard, F. Pepe, M. Soleimani, P. Aprea, and D. Caputo, "Iron-activated carbon nanocomposite: synthesis, characterization and application for lead removal from aqueous solution," RSC Advances, vol. 6, no. 49, pp. 42845-42853, 2016.

[109] L. Yang and A. Merneedi, "Experimental investigation on wear behaviour of bio-waste reinforced fusion fiber composite laminate under various conditions," Materials Today: Proceedings, vol. 37, no. 2, pp. 1486-1490, 2021.

[110] L.-J. Xie, J.-F. Wu, C.-M. Chen et al., "A novel asymmetric supercapacitor with an activated carbon cathode and a reduced graphene oxide-cobalt oxide nanocomposite anode," Journal of Power Sources, vol. 242, pp. 148-156, 2013.

[111] R. Li, Y. Liu, L. Cheng, C. Yang, and J. Zhang, "Photoelectrochemical aptasensing of kanamycin using visible lightactivated carbon nitride and graphene oxide nanocomposites," Analytical Chemistry, vol. 86, no. 19, pp. 9372-9375, 2014.

[112] J. Xu, P. Xin, Y. Gao et al., "Magnetic properties and methylene blue adsorptive performance of $\mathrm{CoFe}_{2} \mathrm{O}_{4}$ /activated carbon nanocomposites," Materials Chemistry and Physics, vol. 147, no. 3, pp. 915-919, 2014.

[113] E. Altintig and S. Kirkil, "Preparation and properties of Ag-coated activated carbon nanocomposites produced from wild chestnut shell by $\mathrm{ZnCl}_{2}$ activation," Journal of the Taiwan Institute of Chemical Engineers, vol. 63, pp. 180-188, 2016.

[114] T. A. Saleh, K. O. Sulaiman, S. A. AL-Hammadi, H. Dafalla, and G. I. Danmaliki, "Adsorptive desulfurization of thiophene, benzothiophene and dibenzothiophene over activated carbon manganese oxide nanocomposite: with column system evaluation," Journal of Cleaner Production, vol. 154, pp. 401-412, 2017.

[115] Y.-F. Lee, K.-H. Chang, C.-C. Hu, and K.-M. Lin, "Synthesis of activated carbon-surrounded and carbon-doped anatase $\mathrm{TiO}_{2}$ nanocomposites," Journal of Materials Chemistry, vol. 20 , no. 27 , pp. 5682-5688, 2010. 
[116] D. Deng, B.-S. Kim, M. Gopiraman, and I. S. Kim, "Needlelike $\mathrm{MnO}_{2}$ /activated carbon nanocomposites derived from human hair as versatile electrode materials for supercapacitors," RSC Advances, vol. 5, no. 99, pp. 81492-81498, 2015.

[117] B. B. Zhang, J. C. Xu, P. H. Xin et al., "Magnetic properties and adsorptive performance of manganese-zinc ferrites/activated carbon nanocomposites," Journal of Solid State Chemistry, vol. 221, pp. 302-305, 2015.

[118] J. Matos, P. S. Poon, R. Montaña et al., "Photocatalytic activity of P-Fe/activated carbon nanocomposites under artificial solar irradiation," Catalysis Today, vol. 356, pp. 226-240, 2020.

[119] D. N. Sangeetha, D. Krishna Bhat, and M. Selvakumar, "h$\mathrm{MoO}_{3} /$ Activated carbon nanocomposites for electrochemical applications," Ionics, vol. 25, no. 2, pp. 607-616, 2019.

[120] G. Sharma, D. D. Dionysiou, S. Sharma et al., "Highly efficient $\mathrm{Sr} / \mathrm{Ce} / \mathrm{activated}$ carbon bimetallic nanocomposite for photoinduced degradation of rhodamine B," Catalysis Today, vol. 335, pp. 437-451, 2019.

[121] G. Bharath, K. Rambabu, F. Banat, A. Hai, A. F. Arangadi, and N. Ponpandian, "Enhanced electrochemical performances of peanut shell derived activated carbon and its $\mathrm{Fe}_{3} \mathrm{O}_{4}$ nanocomposites for capacitive deionization of $\mathrm{Cr}(\mathrm{VI})$ ions," Science of the Total Environment, vol. 691, pp. 713726, 2019.

[122] J. Yang, B. Hou, J. Wang et al., "Nanomaterials for the removal of heavy metals from wastewater," Nanomaterials, vol. 9, no. 3, p. 424, 2019.

[123] F. Keyvani, S. Rahpeima, and V. Javanbakht, "Synthesis of EDTA-modified magnetic activated carbon nanocomposite for removal of permanganate from aqueous solutions," Solid State Sciences, vol. 83, pp. 31-42, 2018.

[124] F. Cao, M. Zhao, Y. Yu et al., "Synthesis of two-dimensional CoS1. 097/nitrogen-doped carbon nanocomposites using metal-organic framework nanosheets as precursors for supercapacitor application," Journal of the American Chemical Society, vol. 138, no. 22, pp. 6924-6927, 2016.

[125] Y. Peng, Z. Chen, J. Wen et al., "Hierarchical manganese oxide/carbon nanocomposites for supercapacitor electrodes," Nano Research, vol. 4, no. 2, pp. 216-225, 2011.

[126] C. Yang, M. Zhou, and Q. Xu, “Three-dimensional ordered macroporous $\mathrm{MnO}$ 2/carbon nanocomposites as highperformance electrodes for asymmetric supercapacitors," Physical Chemistry Chemical Physics, vol. 15, no. 45, pp. 19730-19740, 2013.

[127] H. Li, L. Jiang, Q. Cheng et al., " $\mathrm{MnO}_{2}$ nanoflakes/hierarchical porous carbon nanocomposites for high-performance supercapacitor electrodes," Electrochimica Acta, vol. 164, pp. 252-259, 2015.

[128] Y. Yan, Q. Cheng, Z. Zhu, V. Pavlinek, P. Saha, and C. Li, "Controlled synthesis of hierarchical polyaniline nanowires/ordered bimodal mesoporous carbon nanocomposites with high surface area for supercapacitor electrodes," Journal of Power Sources, vol. 240, pp. 544-550, 2013.

[129] J.-S. Ye, H. F. Cui, X. Liu, T. M. Lim, W.-D. Zhang, and F.S. Sheu, "Preparation and characterization of aligned carbon nanotube-ruthenium oxide nanocomposites for supercapacitors," Small, vol. 1, no. 5, pp. 560-565, 2005.

[130] J. Shi, B. Jiang, C. Li et al., "Review of transition metal nitrides and transition metal nitrides/carbon nanocomposites for supercapacitor electrodes," Materials Chemistry and Physics, vol. 245, article 122533, 2020.
[131] P. Liu, J. Yan, Z. Guang, Y. Huang, X. Li, and W. Huang, "Recent advancements of polyaniline-based nanocomposites for supercapacitors," Journal of Power Sources, vol. 424, pp. 108-130, 2019.

[132] X. Zhong, X. Li, Y. Zhuo, Y. Chai, and R. Yuan, "Synthesizing anode electrochemiluminescent self-catalyzed carbon dotsbased nanocomposites and its application in sensitive ECL biosensor for microRNA detection," Sensors and Actuators B: Chemical, vol. 305, p. 127490, 2020.

[133] V. Gupta and R. K. Kotnala, "Multifunctional ferromagnetic carbon-nanotube arrays prepared by pulse-injection chemical vapor deposition," Angewandte Chemie International Edition, vol. 51, no. 12, pp. 2916-2919, 2012.

[134] Z. Wei, H. Wang, Z. Ma, and H. Han, “Amperometric biosensor of matrix metalloproteinase-7 enhanced by Pdfunctionalized carbon nanocomposites," Nanoscale Research Letters, vol. 13, no. 1, p. 375, 2018.

[135] S. Selvarajan, A. Suganthi, and M. Rajarajan, "Fabrication of g- $\mathrm{C}_{3} \mathrm{~N}_{4} / \mathrm{NiO}$ heterostructured nanocomposite modified glassy carbon electrode for quercetin biosensor," Ultrasonics Sonochemistry, vol. 41, pp. 651-660, 2018.

[136] S. Shrivastava, N. Jadon, and R. Jain, "Next-generation polymer nanocomposite-based electrochemical sensors and biosensors: a review," TrAC Trends in Analytical Chemistry, vol. 82, pp. 55-67, 2016.

[137] R. Madhu, V. Veeramani, S.-M. Chen, P. Veerakumar, S.B. Liu, and N. Miyamoto, "Functional porous carbon-ZnO nanocomposites for high-performance biosensors and energy storage applications," Physical Chemistry Chemical Physics, vol. 18, no. 24, pp. 16466-16475, 2016.

[138] Q. Zhang, Y. Qing, X. Huang, C. Li, and J. Xue, "Synthesis of single-walled carbon nanotubes-chitosan nanocomposites for the development of an electrochemical biosensor for serum leptin detection," Materials Letters, vol. 211, pp. 348351, 2018.

[139] A. Şavk, H. Aydın, K. Cellat, and F. Şen, "A novel high performance non-enzymatic electrochemical glucose biosensor based on activated carbon-supported Pt-Ni nanocomposite," Journal of Molecular Liquids, vol. 300, article 112355, 2020.

[140] A. Hassanein, N. Salahuddin, A. Matsuda, G. Kawamura, and M. Elfiky, "Fabrication of biosensor based on Chitosan$\mathrm{ZnO} /$ Polypyrrole nanocomposite modified carbon paste electrode for electroanalytical application," Materials Science and Engineering: C, vol. 80, pp. 494-501, 2017.

[141] N. Kaur, H. Thakur, and N. Prabhakar, "Conducting polymer and multi-walled carbon nanotubes nanocomposites based amperometric biosensor for detection of organophosphate," Journal of Electroanalytical Chemistry, vol. 775, pp. 121$128,2016$.

[142] N. A. Alenazi, M. A. Hussein, K. A. Alamry, and A. M. Asiri, "Nanocomposite-based aminated polyethersulfone and carboxylate activated carbon for environmental application. A real sample analysis," C-Journal of Carbon Research, vol. 4, no. 2, p. 30, 2018.

[143] F. O. Gomes, L. B. Maia, C. Delerue-Matos, I. Moura, J. J. G. Moura, and S. Morais, "Third-generation electrochemical biosensor based on nitric oxide reductase immobilized in a multiwalled carbon nanotubes/1- $n$-butyl-3-methylimidazolium tetrafluoroborate nanocomposite for nitric oxide detection," Sensors and Actuators B: Chemical, vol. 285, pp. 445452, 2019. 
[144] A. T. Lawal, "Synthesis and utilization of carbon nanotubes for fabrication of electrochemical biosensors," Materials Research Bulletin, vol. 73, pp. 308-350, 2016.

[145] S. Chaemsanit, N. Matan, and N. Matan, "Activated carbon for food packaging Application: Review," Walailak Journal of Science and Technology (WJST), vol. 15, no. 4, pp. 255271, 2018.

[146] I. Heras, M. Krause, G. Abrasonis et al., "Advanced characterization and optical simulation for the design of solar selective coatings based on carbon: transition metal carbide nanocomposites," Solar Energy Materials and Solar Cells, vol. 157, pp. 580-590, 2016.

[147] H. Hou, H. Shao, X. Zhang, G. Liu, S. Hussain, and G. Qiao, "RGO-loaded flower-like $\mathrm{ZnCo}_{2} \mathrm{O}_{4}$ nanohybrid as counter electrode for dye-sensitized solar cells," Materials Letters, vol. 225, pp. 5-8, 2018.

[148] K. Xiong, W. Nie, P. Yu, L. Zhu, and X. Xiao, "Flower-like $\mathrm{CuCo}_{2} \mathrm{O}_{4} @ \mathrm{RGO}$ nanohybrid as an effective counter electrode for dye-sensitized solar cells," Materials Letters, vol. 204, pp. 69-72, 2017.

[149] I. M. A. Mohamed, V.-D. Dao, A. S. Yasin et al., "Physicochemical and photo-electrochemical characterization of novel $\mathrm{N}$-doped nanocomposite $\mathrm{ZrO}_{2} / \mathrm{TiO}_{2}$ photoanode towards technology of dye-sensitized solar cells," Materials Characterization, vol. 127, pp. 357-364, 2017.

[150] M. Q. Hamzah, A. H. Jabbar, S. O. Mezan, A. N. Tuama, and M. A. Agam, "Fabrications of $\mathrm{PS} / \mathrm{TiO} 2$ nanocomposite for solar cells applications," AIP Conference Proceedings, vol. 2151, no. 1, article 020011, 2019.

[151] S. Chauhan, N. Jain, and U. Nagaich, "Nanodiamonds with powerful ability for drug delivery and biomedical applications: recent updates on in vivo study and patents," Journal of Pharmaceutical Analysis, vol. 10, no. 1, pp. 1-12, 2020.

[152] M. Karimi-Nazarabad and E. K. Goharshadi, "Highly efficient photocatalytic and photoelectrocatalytic activity of solar light driven $\mathrm{WO}_{3} / \mathrm{g}-\mathrm{C}_{3} \mathrm{~N}_{4}$ nanocomposite," Solar Energy Materials and Solar Cells, vol. 160, pp. 484-493, 2017.

[153] S.-A. Martel-Estrada, Recent progress in biomedical applications of nanodiamonds, Instituto de Arquitectura Diseño y Arte, 2018.

[154] R. Zentel, "Polymer coated semiconducting nanoparticles for hybrid materials," Inorganics, vol. 8, no. 3, p. 20, 2020.

[155] A. Kausar, "Polydimethylsiloxane-based nanocomposite: present research scenario and emergent future trends," Polymer-Plastics Technology and Materials, vol. 59, no. 11, pp. 1148-1166, 2020.

[156] A. V. Penkova, S. F. A. Acquah, L. B. Piotrovskiy, D. A. Markelov, A. S. Semisalova, and H. W. Kroto, "Fullerene derivatives as nano-additives in polymer composites," Russian Chemical Reviews, vol. 86, no. 6, pp. 530-566, 2017.

[157] P. Senthil Kumar, P. R. Yaashikaa, and S. Ramalingam, "Efficient removal of nitrate and phosphate using graphene nanocomposites," in A New Generation Material Graphene: Applications in Water Technology, pp. 287-307, Springer, Cham, 2019.

[158] I. M. A. Mohamed, V.-D. Dao, C. Liu, N. A. M. Barakat, and H.-S. Choi, "Synthesis of electrospun 1D-photoanode nanocomposite based on electrospinning followed by hydrothermal treatment for highly efficient liquid-junction photovoltaic devices," Journal of Sol-Gel Science and Technology, vol. 91, no. 2, pp. 342-352, 2019.
[159] P. S. Nagasree, K. Ramji, K. K. Murthy, M. Kannam Naidu, and T. Haritha, "Fibre reinforced polymer (FRP) nanocomposites for radar absorption application in the X-band," in Recent Trends in Mechanical Engineering, pp. 409-418, Springer, Singapore, 2020.

[160] A. Munir, "Microwave radar absorbing properties of multiwalled carbon nanotubes polymer composites: a review," Advances in Polymer Technology, vol. 36, no. 3, pp. 362370, 2017.

[161] B. K. Nagesha, V. Dhinakaran, M. Varsha Shree, K. P. Manoj Kumar, and T. Jagadeesha, "A review on weldability of additive manufactured titanium alloys," Materials Today: Proceedings, vol. 33, pp. 2964-2969, 2020.

[162] S. Tyagi, V. S. Pandey, H. B. Baskey et al., "RADAR absorption study of $\mathrm{BaFe}_{12} \mathrm{O}_{19} / \mathrm{ZnFe}_{2} \mathrm{O}_{4} / \mathrm{CNT}$ nanocomposite," Journal of Alloys and Compounds, vol. 731, pp. 584-590, 2018.

[163] N. Rezazadeh and A. Kianvash, "Flexible radar absorbing nanocomposites based on co-ferrite/nano carbon/polymeric epoxy resin," Journal of Electrical and Computer Engineering Innovations, vol. 5, no. 1, pp. 53-57, 2017.

[164] V. Dhinakaran, N. Suraj Khope, S. Shanmugam, and K. Sankaranarayanasamy, "Numerical prediction of weld bead geometry in plasma arc welding of titanium sheets using COMSOL," in Proceedings of the 2014 COMSOL Conference in Bangalore, pp. 13-14, Bangalore, India, 2014.

[165] S.-E. Lee, W.-J. Lee, K. S. Oh, and C.-G. Kim, "Broadband all fiber-reinforced composite radar absorbing structure integrated by inductive frequency selective carbon fiber fabric and carbon-nanotube- loaded glass fabrics," Carbon, vol. 107, pp. 564-572, 2016.

[166] V. Dhinakaran, K. V. Surendar, M. S. Hasunfur Riyaz, and M. Ravichandran, "Review on study of thermosetting and thermoplastic materials in the automated fiber placement process," Materials Today: Proceedings, vol. 27, pp. 812815,2020 .

[167] L. Sha, P. Gao, T. Wu, and Y. Chen, "Chemical Ni-C bonding in $\mathrm{Ni}$-carbon nanotube composite by a microwave welding method and its induced high-frequency radar frequency electromagnetic wave absorption," ACS Applied Materials \& Interfaces, vol. 9, no. 46, pp. 40412-40419, 2017.

[168] S.-H. Chen, W.-S. Kuo, and R.-B. Yang, "Microwave absorbing properties of a radar absorbing structure composed of carbon nanotube papers/glass fabric composites," International Journal of Applied Ceramic Technology, vol. 16, no. 5, pp. 2065-2072, 2019.

[169] H. Karimi-Maleh, Y. Orooji, F. Karimi et al., "A critical review on the use of potentiometric based biosensors for biomarkers detection," Biosensors and Bioelectronics, vol. 184, article 113252, 2021.

[170] S. A. Abid, A. Ahmed Muneer, I. M. S. al-Kadmy et al., "Biosensors as a future diagnostic approach for COVID-19," Life Sciences, vol. 273, article 119117, 2021.

[171] P. Li, G.-H. Lee, S. Y. Kim, S. Y. Kwon, H.-R. Kim, and S. Park, "From diagnosis to treatment: recent advances in patient-friendly biosensors and implantable devices," ACS Nano, vol. 15, no. 2, pp. 1960-2004, 2021.

[172] R. Antiochia, "Developments in biosensors for CoV detection and future trends," Biosensors and Bioelectronics, vol. 173, article 112777, 2021.

[173] J. Min, J. R. Sempionatto, H. Teymourian, J. Wang, and W. Gao, "Wearable electrochemical biosensors in North 
America," Biosensors and Bioelectronics, vol. 172, article 112750, 2021.

[174] X. Zheng, F. Zhang, K. Wang et al., "Smart biosensors and intelligent devices for salivary biomarker detection," TrAC Trends in Analytical Chemistry, vol. 140, article 116281, 2021.

[175] M. M. Rahman, M. M. Hussain, and A. M. Asiri, "Fabrication of 3-methoxyphenol sensor based on $\mathrm{Fe} 3 \mathrm{O} 4$ decorated carbon nanotube nanocomposites for environmental safety: real sample analyses," PLoS One, vol. 12, no. 9, article e0177817, 2017.

[176] L. Qian, S. Durairaj, S. Prins, and A. Chen, "Nanomaterialbased electrochemical sensors and biosensors for the detection of pharmaceutical compounds," Biosensors and Bioelectronics, vol. 175, article 112836, 2021.

[177] T. Yu, D. Liu, and Y. Xianyu, "Recent advances in gold nanoparticles-based biosensors for food safety detection," Biosensors and Bioelectronics, vol. 179, article 113076, 2021.

[178] Y. Nasu, Y. Shen, L. Kramer, and R. E. Campbell, "Structureand mechanism-guided design of single fluorescent proteinbased biosensors," Nature Chemical Biology, vol. 17, no. 5, pp. 509-518, 2021.

[179] A. A. Ansari, M. K. Nazeeruddin, and M. M. Tavakoli, "Organic-inorganic upconversion nanoparticles hybrid in dye-sensitized solar cells," Coordination Chemistry Reviews, vol. 436, article 213805, 2021.

[180] D. Zhang, M. Stojanovic, Y. Ren et al., "A molecular photosensitizer achieves a $V_{\text {oc }}$ of $1.24 \mathrm{~V}$ enabling highly efficient and stable dye-sensitized solar cells with copper(II/I)-based electrolyte," Nature communications, vol. 12, no. 1, article 1777, pp. 1-10, 2021.

[181] D. Vikraman, S. Hussain, S. A. Patil et al., "Engineering MoSe2/WS2Hybrids to replace the scarce platinum electrode for hydrogen evolution reactions and dye-sensitized solar cells," ACS Applied Materials \& Interfaces, vol. 13, no. 4, pp. 5061-5072, 2021.

[182] N. Vlachopoulos, A. Hagfeldt, I. Benesperi et al., "New approaches in component design for dye-sensitized solar cells," Sustainable Energy \& Fuels, vol. 5, no. 2, pp. 367383, 2021.

[183] J. Weerasinghe, S. Sen, J. M. K. W. Kumari et al., "Efficiency enhancement of low-cost metal free dye sensitized solar cells via non-thermal atmospheric pressure plasma surface treatment," Solar Energy, vol. 215, pp. 367-374, 2021.

[184] G. Fu, E. J. Cho, X. Luo et al., "Enhanced light harvesting in panchromatic double dye-sensitized solar cells incorporated with bilayered $\mathrm{TiO}_{2}$ thin film-based photoelectrodes," Solar Energy, vol. 218, pp. 346-353, 2021.

[185] M. Dhonde, K. Sahu, and V. V. S. Murty, "Cu-doped $\mathrm{TiO}_{2}$ nanoparticles/graphene composites for efficient dyesensitized solar cells," Solar Energy, vol. 220, pp. 418-424, 2021.

[186] H. Zhou, J.-M. Ji, and H. K. Kim, "Porphyrin sensitizers with acceptor structural engineering for dye-sensitized solar cells," Dyes and Pigments, vol. 187, article 109082, 2021.

[187] C. Kim and M. Kim, "Intrinsically conducting polymer (ICP) coated aramid fiber reinforced composites for broadband radar absorbing structures (RAS)," Composites Science and Technology, vol. 211, article 108827, 2021.

[188] M.-S. Jang, J.-H. Choi, W.-H. Jang, Y.-W. Nam, and C.G. Kim, "Effects of dot-type electroless nickel plating on the mechanical properties of glass/epoxy used for radarabsorbing structures," Composite Structures, vol. 257, article 113165, 2021.

[189] V. Joy, V. G. Padwal, H. Singh, and R. U. Nair, Optimization of Multilayered Radar Absorbing Structures (RAS) Using Nature Inspired Algorithm, CRC Press, 2021.

[190] S. M. Baek and W. J. Lee, "Design method for radar absorbing structures using reliability-based design optimization of the composite material properties," Composite Structures, vol. 262, article 113559, 2021.

[191] A. F. N. Boss, H. R. Ferreira, F. L. Braghiroli et al., "Investigation of sustainable porous carbon as radar absorbing material," Matéria (Rio de Janeiro), vol. 26, no. 2, 2021.

[192] Y. R. Denny, A. Trenggono, T. Firmansyah, I. Revaldi, Y. Taryana, and S. Aritonang, "Effect of filler concentration and time sonication of $\mathrm{ZnO}$ composite for radar absorbing material applications," Materials Science Forum, vol. 1028, pp. 249-254, 2021.

[193] Y. Xie, P. Li, J. Tang et al., "Highly thermally conductive and superior electromagnetic interference shielding composites via in situ microwave-assisted reduction/exfoliation of expandable graphite," Composites Part A: Applied Science and Manufacturing, vol. 149, article 106517, 2021.

[194] D. V. Baker, C. Bao, and W. S. Kim, "Highly conductive 3D printable materials for 3D structural electronics," ACS Applied Electronic Materials, vol. 3, no. 6, pp. 2423-2433, 2021.

[195] E. Ragni, C. Perucca Orfei, A. Bidossi et al., "Superior osteoinductive and osteo-conductive properties of trabecular titanium vs. PEEK scaffolds on human mesenchymal stem cells: a proof of concept for the use of fusion cages," International journal of molecular sciences, vol. 22, no. 5, article 2379, 2021.

[196] B. Zhao, Q. Chen, G. da, J. Yao, Z. Shao, and X. Chen, “A Highly stretchable and anti-freezing silk-based conductive hydrogel for application as a self-adhesive and transparent ionotronic skin," Journal of Materials Chemistry C, vol. 9, no. 28, pp. 8955-8965, 2021.

[197] V. Katseli, A. Economou, and C. Kokkinos, "Smartphoneaddressable 3D-printed electrochemical ring for nonenzymatic self-monitoring of glucose in human sweat," Analytical Chemistry, vol. 93, no. 7, pp. 3331-3336, 2021.

[198] J. Chen, Y. Zhu, J. Huang et al., "Advances in responsively conductive polymer composites and sensing applications," Polymer Reviews, vol. 61, no. 1, pp. 157-193, 2021.

[199] D. Serban and C. G. Opran, "Influence of the surface microstructure of conductive polymer composite bipolar plate on the fuel cell performance," Macromolecular Symposia, vol. 396, no. 1, article 2000324, 2021.

[200] Y. Guan, F. Xu, X. Wang et al., "Implementation of hybrid PDMS-graphite/Ag conductive material for flexible electronic devices and microfluidic applications," Microelectronic Engineering, vol. 235, article 111455, 2021.

[201] S.-M. Yong, S. J. Lee, J. Park, J. Hong, J. H. Jung, and Y. Kim, "Fiber-reinforced plastic material with de-icing capability for radome application," Materials Letters, vol. 284, article 128943, 2021.

[202] D. Kim, Y. Hirayama, Z. Liu, H. Kwon, M. Kobashi, and $\mathrm{K}$. Takagi, "Highly conductive $\mathrm{Al} / \mathrm{Al}$ interfaces in ultrafine grained $\mathrm{Al}$ compact prepared by low oxygen powder metallurgy technique," Nanomaterials, vol. 11, no. 5, p. 1182, 2021. 
[203] Q. Zou, S.-w. Xiong, M.-y. Jiang et al., "Highly thermally conductive and eco-friendly $\mathrm{OH}-\mathrm{h}-\mathrm{BN} /$ chitosan nanocomposites by constructing a honeycomb thermal network," Carbohydrate Polymers, vol. 266, article 118127, 2021.

[204] N. Zavanelli and W.-H. Yeo, "Advances in screen printing of conductive nanomaterials for stretchable electronics," ACS Omega, vol. 6, no. 14, pp. 9344-9351, 2021.

[205] A. Wang, Y. Wang, B. Zhang et al., "Hydrogen-bonded network enables semi-interpenetrating ionic conductive hydrogels with high stretchability and excellent fatigue resistance for capacitive/resistive bimodal sensors," Chemical Engineering Journal, vol. 411, article 128506, 2021. 